Maurer School of Law: Indiana University

Digital Repository @ Maurer Law

1981

\title{
Property As Government in Eighteenth-Century America: The Case of New York City
}

Hendrik Hartog

Indiana University School of Law

Follow this and additional works at: https://www.repository.law.indiana.edu/facpub

Part of the Legal History Commons, and the State and Local Government Law Commons

\section{Recommended Citation}

Hartog, Hendrik, "Property As Government in Eighteenth-Century America: The Case of New York City" (1981). Articles by Maurer Faculty. 1918.

https://www.repository.law.indiana.edu/facpub/1918

This Article is brought to you for free and open access by the Faculty Scholarship at Digital Repository @ Maurer Law. It has been accepted for inclusion in Articles by Maurer Faculty by an authorized administrator of Digital Repository @ Maurer Law. For more information, please contact rvaughan@indiana.edu. 


\title{
PROPERTY AS GOVERNMENT IN EIGHTEENTH-CENTURY AMERICA: THE CASE OF NEW YORK CITY
}

\author{
HENDRIK HARTOG*
}

\section{INTRODUCTION}

F OR 150 years it has been the central premise of local government law that legitimate governmental action is always distinctively public in character. The most eminent modern student of local government law has written that: "We know perfectly well, granting that there are intermediate hard cases, how to distinguish governmental from nongovernmental powers and forms of organization: governments are distinguished by their acknowledged, lawful authority-not dependent on property ownership-to coerce a territorially defined and imperfectly voluntary membership by acts of regulation, taxation, and condemnation." "The most eminent local government lawyer of an earlier generation declared that the distinction between public and private spheres could not be "too much emphasized"' and founded his conception of a properly public institution on its total dependence on a legislative delegation of public authority. ${ }^{3}$ The assumption that local governments act as governments only to the extent they decisively separate themselves from the world of the marketplace and demonstrate their independence from private sources of power and wealth lies deep within our collective perceptions of the political and legal nature of communities in America. ${ }^{4}$ We all "know" that private wealth corrupts public authority and that the

* Assistant Professor of Law, Indiana University School of Law, Bloomington. I am indebted to Michael Grossberg, Morton Keller, William Nelson, and Susan Willey for reading and commenting on earlier versions of this paper.

1 Frank I. Michelman, States' Rights and States' Roles: Permutations of "Sovereignty" in National League of Cities v. Usery, 86 Yale L. J. 1165, 1167 (1977) (fn omitted).

2 John F. Dillon, Treatise on the Law of Municipal Corporations 70 (1872).

${ }^{3} \mathrm{Id}$. at $70-76$ and passim.

4 See Frank I. Michelman \& Terence Sandalow, Materials on Government in Urban Areas (1970), particularly at 155-97.

[The Journal of Legal Studies, Volume X, June 1981]

(C) 1981 by The University of Chicago. $0047-2530 / 81 / 1002-0006 \$ 01.50$ 
boundaries of local authority are properly defined by the public power of the state. ${ }^{5}$

Indeed, the notion of an antinomic relationship between public and private, the belief in a sharp division of our conceptural universe into mutually exclusive spheres, has often appeared as a natural and inevitable fact of legal life. In the case of New York City, this "fact" had been established by 1826. That year Judge Savage of the New York Supreme Court ruled that the capacity of the Corporation of the City of New York to "purchase and hold, sell and convey real estate, in the same manner as individuals" was absolutely unrelated to its activities as the government of the city. ${ }^{6}$ Governance was defined by the Corporation's powers and duties as an agent of the state legislature; as a public institution, the Corporation had no right to make any contract or agreement that would "control or embarrass"' its legislative responsibilities. Public welfarethe goal of governmental action-could only be secured through delegations of the public power of the sovereign state of New York.

By the second quarter of the nineteenth century such attitudes had already become a kind of conventional wisdom. Even today it remains difficult to formulate an alternative perception of the appropriate relationship between governmental action and political sovereignty. ${ }^{7}$ Yet, half a century before the Brick Presbyterian Church case of 1826, an assertion of the distinctively public and unpropertied character of New York City's government would have been incomprehensible to those who ran that government. In prerevolutionary New York City, governmental action was based not on power derived from the provincial legislature, but on the property rights granted to the city government by its royal charter. Property authorized and legitimated the actions of the city; property, in fact, permitted New York City's government to act in ways that were beyond the reach of other, unchartered or unpropertied local governments. It was the estate granted in its charters that shaped New York's relatively autonomous relationship with external political authority. Likewise, it was the active use of "private" wealth that allowed eighteenth-century city government to satisfy the wants of a growing commercial city. How property became a tool of city government and how the propertied actions of New York City could be justified within the political culture of eighteenth-century America are the subjects of this essay.

${ }^{5}$ People v. Morris, 13 Wend. 325 (N.Y. Sup. Ct. 1835); Hunter v. City of Pittsburgh, 207 U.S. 161 (1907); Hendrik Hartog, Because All the World Was Not New York City: Governance, Property Rights, and the State in the Changing Definition of a Corporation, 1730-1860, 28 Buffalo L. Rev. 91, 92-96 (1979).

${ }^{6}$ Brick Presbyterian Church v. Mayor of New York, 5 Cow. 538 (N.Y. 1826).

7 But see Gerald Frug, The City as a Legal Concept, 93 Harv. L. Rev. 1057 (1980). 


\section{READing The Charter}

\section{A. The Properties of the Charter}

Let us begin with the fact that legally New York City was a corporation. ${ }^{8}$ It might be supposed that, as a corporation, New York City has always been the same. In 1731 as in 1981 New York City was "an artificial person or legal entity created by or under the authority of the laws of a state or nation . . . a body politic ... regarded as having a personality and existence distinct from that of its several members.' 9 Yet the constancy of that definition should not mislead us. As a legal entity, New York City underwent radical changes. The law-dictionary definition only hides the depth of the conceptual transformation. In 1826 Judge Savage regarded New York City primarily as a member of a general category of agencies of public welfare; an eighteenth-century judge, by contrast, could only have looked to the chartered foundations of a propertied corporation. When our imaginary eighteenth-century judge searched for authority to justify action by the institution, he would have had to turn to the charters which created the city as a corporation. There was no general category of public institutions. There were only the particular powers granted to the singular institution of the city of New York by the various charters culminating in the Montgomerie Charter of 1730.

To modern eyes the Montgomerie Charter is an awkward, prolix, and repetitious document. The language is archaic, the structure mystifying. It begins by reciting and incorporating the city's previous English charters of 1686 (the Dongan Charter) and 1708 (the Cornbury ferry grant). It finishes by announcing that the city will be free from any liability for the use or misuse of powers or properties not granted by the charters. ${ }^{10}$ Throughout, it contains a seemingly disorganized series of grants from the crown to the Corporation.

The need for a new charter arose because of the "diverse Questions Doubts Opinions Ambiguities Controversies and Debates' concerning the validity of the previous two charters, neither of which had been under royal seal. ${ }^{11}$ The purpose of the Montgomerie Charter therefore was both

\footnotetext{
8 Throughout I shall indiscriminately use "the Corporation," "the city," or "New York City," as referents for "The Mayor, Aldermen and Commonalty of the City of New York." Note that I am thereby equating the city with the Corporation. I demonstrate that this is a plausible equation in Part Two of this essay.

9 Black's Law Dictionary 409 (rev'd 4th ed. 1968).

10 For more on the significance of this release from liability see text at notes 44 \& 45 infra.

1 Colonial Laws of New York from the Year 1664 to the Revolution 575, 596-97 (J. B. Lyon edition 1894) [hereinafter cited as Colonial Laws]. [Copies of the Montgomerie charter
} 
to confirm what had been previously granted or acquired by the city and to provide new powers and rights. "Considering that the Strength and Encrease of our good Subjects in that our frontier province of New York does in a greater measure depend upon the wellfare and properity of our said City wherein the Trade and Navigation thereof are chiefly and principally carried on," the charter was drafted "to give Encouragement to the said City Inhabitants and Citizens and to remove utterly abolish and wholly take away all and all manner of Causes Occasions and matters whereupon Such Questions Doubts Opinions Ambiguities Controversies or Debates . . . may or can arise." 12

What it granted can be divided into three categories. There were first the incidents of corporate existence itself. The Mayor, Alderman, and Commonalty were made "by force of these presents" one body corporate and politic, with perpetual succession, the capacity to get, receive, and possess all forms of property, to give, grant, let, or assign the same, and to sue and be sued in courts of law "in as full and ample manner and form as any of our other Liege Subjects of our Said Province." The charter made the City a singular individual, a person like other persons capable of holding property both within and without the city limits ${ }^{13}$ and a person with a tangible and specific shape. New York City was given a head in the creation of a structure of elective and appointive officers; it received a body in the identification of the commonalty - the freeman and freeholders of the city-with the interests of the Corporation. No free citizen of the city could be compelled to serve on any jury, fill any office, or discharge any public duty to any local government outside of the city. His only local responsibilities were to the Corporation. Only the Corporation could claim his allegiance. ${ }^{14}$

Secondly, and to city leaders most importantly, the charters confirmed and extended the corporate estate of the city. External threats to the title of the city had provided the impetus to petitions for a new charter. In 1708 it was the attempt by Cornelius Sebring of Brooklyn to establish a competing ferry across the East River in derogation of alleged rights of the city; in 1730 it was the petition of Cornelius Van Horne to the Governor for a grant of a waterlot out beyond low water mark to build dock facilities. ${ }^{15}$ In both of these cases city leaders gained the secure title they had sought.

are available in James Kent, The Charter of the City of New York . . . (1836, 1851); Colonial Charters, Patents, and Grants to the Communities Comprising the City of New York (Jerrold Seymann ed. 1939); and in many other editions published in the eighteenth and nineteenth centuries, as well as in the colonial laws. References throughout will be to Colonial Laws.]

${ }^{12} I d$.

${ }^{13}$ Id. at $581,587,597$.

${ }^{14} I d$. at $602-11,615-16$.

152 Minutes of the Common Council of the City of New York 1675-1776, at 341-45 (8 vols. 
The Montgomerie Charter gave them more than that, however. All the "waste and common land" of Manhattan Island, which at the time included most of the island north of what is now Canal Street, all the land under water surrounding the island as far as low water mark plus an extra 400 feet beyond low water mark around the southern end of the island, a ferry monopoly, all of the waterfront on the Long Island shore opposite the city were granted in fee simple absolute to the Corporation of the city of New York.

In addition, the Montgomerie Charter granted to the city what might be regarded as a hodgepodge of public governmental powers. A common council was given the power to pass such ordinances or by-laws "which to them or the greater part of them Shall Seem to be good usefull or necessary for the good rule and government of the body corporate."16 Specifically, the Charter authorized that body to pass regulations "for the further publick good common proffit trade and better government and rule of the Said City and for the better preserving governing disposing letting and Setting of the Land Tenements possessions and hereditaments goods and Chattels" of the Corporation. ${ }^{17}$ The common council could investigate and pass on the election of all officers of the Corporation (except for the mayor who was appointed by the governor). ${ }^{18}$ It also had authority to lay out and open streets, to run and regulate the markets of the city, to regulate and license individuals in a variety of trades, and to appoint inspectors for various goods. ${ }^{19}$ The mayor of the city was made the clerk of the market and the water bailiff for the harbor, in both cases with the authority to collect all fees and rents without any need to account to the agents of the crown. ${ }^{20}$ The charter granted to the Corporation general authority to erect and fill houses of correction (Bridewells), almshouses, and jails. It also created two courts, both manned by officers of the Corporation sitting as justices of the peace, one a court of general sessions of the peace to hear criminal offenses, the other a court of common pleas or Mayor's Court for civil actions. Each court was created with the authority to act "as fully and freely and intirely and in as ample manner and form as Justices of the peace of us and our Heirs and Successors anywhere within that part of our Kingdom of great Britain called England." ${ }^{21}$

1905) [hereinafter cited as Common Council] (ferry); 3 Common Council 221, 271-72, 278 (petition of Cornelius Van Horne).

162 Colonial Laws 610.

${ }^{17}$ Id. at 611.

${ }^{18} \mathrm{Id}$. at 612.

19 Id. at 613-17.

${ }^{20} \mathrm{Id}$. at 618-19.

${ }^{21}$ Id. at 620-23. 


\section{B. Property and the Creation of Autonomy}

What sort of an entity did the charter "create"? The corporation created by the charter resembled no modern governmental entity. More to the point, it resembled few governmental entities in eighteenth-century North America. In the province of New York only Albany also governed by virtue of a charter. No more than seventeen communities in all of colonial America ever received corporate charters. Indeed, the Dongan Charter of 1686 had been granted to give concrete affirmation by central authority of the special status of New York City. According to his instructions from the Duke of York, Governor Dongan was to draft a charter which would grant the city, "immunities and privileges beyond what other parts of my territory doe enjoy." 22

Even as a corporation among other corporations, New York City was a singular institution. Like many historical statements, this seems paradoxical until one realizes that it is actually tautological. For in the eighteenth century what else could a corporation be but a singular institution? Corporations were chartered with particular rights, properties, privileges, and immunities to serve particular purposes. There was no general categorization of different corporate entities. The often noted confusion of Blackstone's discussion of corporations was an accurate reflection of the corporate landscape of eighteenth-century England. To Blackstone, "lay corporations" included the king, towns and cities, manufacturing and commercial concerns like the "trading companies of London," churchwardens, the college of physicians and company of surgeons in London, the Royal Society, the society of antiquaries, Oxford, and Cambridge. ${ }^{23}$ Each of these, as well as a great variety of others, was defined not by its membership in a general category, but by its particular property rights and privileges, by the specific terms of its charter.

So, New York was not a member of a general category of municipal corporations sharing its status with Albany and Philadelphia. ${ }^{24}$ It was a particular institution defined by what it had been granted in its charter. That New York City received "all the waste and common land of Manhattan Island,' while Albany had been granted the monopoly of the fur trade and the right to buy land from the Indians, served less to join them in a common category of propertied corporate communities than to distinguish them by the specific natures of their respective grants. ${ }^{25}$

${ }^{22}$ Marcus Benjamin, Thomas Dongan and the Granting of the New York Charter, 1682-86, in Memorial History of the City of New York 411 (James Grant Wilson ed. 1892).

${ }^{23} 1$ William Blackstone, Commentaries, 459 (facsimile of 1st ed., Univ. of Chicago 1979).

${ }^{24}$ See Judith M. Diamondstone, Philadelphia's Municipal Corporation 1701-1776, 90 Penn. Mag. of Hist. and Bio. 183-201 (1966).

${ }^{25}$ Compare the Dongan Charter to Albany, 1 Colonial Laws 195-216, with the Dongan 
Our concern thus should be less with corporate nature in the abstract than with the function of property in the creation of a corporate personality. Just as we say that an object is described by its properties, so in the eighteenth century a person-whether an institution or a human being-was described by his or her or its property. ${ }^{26}$ It was property, not the political act of incorporation, which gave New York City and other boroughs their political character. ${ }^{27}$

In the seventeenth and eighteenth centuries, property, then, was a guarantee of independence. Without it there was no protection from "the political dependence upon others which constitutes corruption." ${ }^{28}$ "The autonomy that property made possible was not simply a form of resistance to interference. It was closely tied to the very possibility of an individualized personality, to a classical notion of citizenship. Property made it possible for a person to shape an identity rather than to be shaped by external forces.

This notion contained an implicit tension. On the one hand, property was seen as control and as a way to resist change imposed by external authority. But property also implied change and instrumental action, the shaping of an individual future. Yet change in and of itself was no virtue. It was closely linked with instability and corruption and the disorder of the English Civil Wars. All of the negative attributes of change were closely identified with the crown and with central authority. The problem for local governments, as for all persons who wished to retain their autonomy, was to lay a basis for freedom from centralized control, to protect themselves from externally imposed "innovation.",29

Not all forms of property served equally well to guarantee the autonomy of the individual. Real property, by its permanence and its creation of a spatial analogue for personal autonomy, had a preferred posi-

Charter to New York City incorporated into the Montgomerie Charter, 2 Colonial Laws, 575-90.

${ }^{26}$ Indeed, it was their landholdings which had first driven medieval towns to seek charters from the crown in the fourteenth century. See Colin Platt, The English Medieval Town 129, 142 (1976).

27 Indeed, Thomas Madox had taken great pains in Firma Burgi to demonstrate that incorporation could not define or determine the relationships between boroughs and the crown. There were important advantages held by incorporated towns over unincorporated communities, but those advantages related to the internal governance and commerce of cities, not to their partial autonomy within the eighteenth-century polity. Local autonomy, insofar as it existed, was a reflection of the property held by boroughs. Thomas Madox, Firma Burgi 37 ns. (1726).

28 J. G. A. Pocock, Politics, Language, and Time 92 (1973).

${ }^{29}$ Consider the words of Recorder Treby, defending the City of London against the quo warranto action by the Crown in 1682:

". . . all innovations (as this must certainly be a very great one) are dangerous."

8 Howell's State Trials 1039, 1143. 
tion. ${ }^{30}$ But all types of property that were not transitory or easily alienable, that were in some measure permanently identifiable with the identity of an individual might protect autonomy. When the Dongan Charter of 1686 spoke of New York City as "an Antient City" that had "antiently been a body Politick and Corporate" and when it confirmed all of the "Liberties privileges ffranchises rights Royalties ffree Customs Jurisdictions and Immunities which they . . . antiently had held," ${ }_{31}$ the effect was to assert the Corporation's preexisting claim to properties for which there was no formal grant or charter, to assert title by prescription. But prescriptive title was not simply an archaic alternative to adverse possession. A prescriptive right - an anciently held right-was a virtuous, a politically significant right. It was a form of property that could be interposed against change and corruption. It was property that articulated the personality of the holder. ${ }^{32}$

The English history of New York City prior to the granting of the Montgomerie Charter in 1730 was marked by a continuing tension between the desires of the members of the Corporation for new and greater grants from provincial and royal authorities and their inclination to assert forms of preexisting or prescriptive title. Consider two episodes in the history of New York City's claim on the ferry franchise. In September 1683, prior to the Dongan Charter, the Mayor and Aldermen submitted to Governor Dongan one of a number of petitions in which they asked for confirmation of a variety of "privileges" of the Corporation, including the franchise in ferries to Long Island. The governor responded with some exasperation at the unending stream of demands made on him by the Corporation (" that he much wondered [that] having lately granted almost every particular of a large and considerable petition Lately preferred by [the] preceeding Mayor [and] aldermen he should so suddenly Receive another petition ffrom [the] present Magistrates'), and he denied many of the city's requests. In particular he restricted the city's rights over ferries "in any other place but what is already," seemingly a denial of the city's right to a franchise - a monopoly - in the ferry to Long Island. A committee was immediately appointed by the common council to entreat the

\footnotetext{
30 Pocock, supra note 28, at 91; See also the wish-list of New York City in the petition for a new charter in which real property grants-the extension of the bands and limits of the city to 400 feet beyond low water mark, the ferry franchise, and all the docks, ships, and wharves with cranage and wharfage-are given priority over all other things to be desired from the Crown. 4 Common Council, supra note 15, at 6-7 (1730).

312 Colonial Laws $575,577$.

32 On the political significance of customary and prescriptive forms of tenure see E. P. Thompson, The Grid of Inheritance; in Family and Inheritance 328-60 (Jack Goody, Joan Thirsk, \& E. P. Thompson eds. 1976). For the later history of title by prescription, see Morton Horwitz, The Transformation of American Law 43-47 (1977).
} 
governor to remove such restrictions. In March of the following year the restrictions imposed by the governor's letter were removed. They were, wrote Dongan, intended merely as "directions not as Tenure." 33 Tenure-the property right in the ferry franchise-was held by the Corporation as a preexisting right, beyond the reach of central authority.

In January 1708 Cornelius Sebring of Kings County (Brooklyn) petitioned then Governor Cornbury to be granted the right to run a ferry from his farm on Long Island to the city in competition with the Corporation. The petition was underwritten by forty individuals who believed "that such a ferry would be of a considerable advantage to the City \& County if the Prises for Transportacon be not excessive," and the challenge was taken very seriously by the Corporation which immediately remonstrated to the governor. "[T]he inhabitants of the city and corporation," have " peaceably and quietly Possess'd and Enjoy'd"' the various rights and properties granted to them by both the English and the Dutch for over seventy years, "to the great increase of her Majestys Revenue and the Sencible Growth and Advancement of her Majestys said City and Province." Among those various properties, the ferry between the city and Long Island had a preeminent place. The Corporation had spent much in erecting several public buildings that rendered service "commodious." No one had ever complained about the service. The profits had always been applied to the government of the city and were "the only considerable Income left to support the public buildings Bridges Goals Landing places fire and Candle for their Watches, Sallaryes of their officers Bellmen \&c, and to defray the other publick and necessary Charges of the Said City.' But, the competing ferry proposed by Sebring "for his own private Lucre and gain" would "make Considerable Improvements to Ruine and destroy the present ferry the Chief Income and Support of this Corporation." Therefore, because "you [Cornbury] will Ever prefer the publick welfare of so Loyall and Considerable a People as this Corporation,' the petition of Sebring should be rejected. ${ }^{34}$

The argument made by the Corporation-successfully one might add-was that its rights in the ferry were not simply those of a private owner, but rather of a piece with its existence as a flourishing and useful governmental institution. Governance and ownership were intertwined in the conception of the ferry franchise. The city had been shaped by its seventy years of possession of an exclusive franchise, and the "improvements" that might result from competition would destroy this element of its personality.

33 1 Common Council 111, 121, 127.

343 Edmond B. O'Callaghan, Documentary History of the State of New York 25-26 (1849); 2 Common Council 341-44. 
The common council proceeded to petition Cornbury for an enlargement and an absolute confirmation of the grant to the Corporation. By securing both "all the Vacant and unappropriated Ground on Nassaw Island [Long Island] from High water to Low water marke fronting unto this City" and an exclusive franchise in the ferry, the city hoped to prevent competition from future Cornelius Sebrings and "to hinder and prevent that priviledge and Liberty which divers persons now take of Transporting themselves and goods to and from the Island of Nassaw over the Said River without Coming to or Landing at the usual and accustomed place where the said ferry Boats are kept and Appointed to the great loss and damage of the petitioners." 35

The result was the Cornbury Charter, which granted the city all the real property it had requested (the exclusive franchise and the shoreline of Long Island), but which refused to forbid residents from transporting themselves across the river. The ferry, began the Cornbury charter, was held by the city under "diverse antiant Charters and grants by diverse former Governours and Commanders in chief of our said Province.' But the profits thereof had declined because of the inability of the city to control and exclude competition. ${ }^{36}$ Thus the enlargement of the grant by the 1708 charter only made effectual and secure the preexisting ancient claim. But the right of residents of Long Island to transport themselves across the harbour was itself an ancient preexisting right, a prescriptive easement in the property of the corporation. It was, one might say, formative of the personality and the autonomy of the inhabitants of Long Island and, therefore, as inviolate as the title of the Corporation.

The rights granted in the charters of the city of New York did not belong to some archetypal archaic world of customary tenure and hazy group personality. To the contrary, those rights need to be located in an age of great legal change and conflict. Prescriptive, customary forms of tenure were under constant attack throughout the eighteenth century. As E. P. Thompson has written, "Small victories . . . in defence of customary practice, were won here and there. But the campaign itself was always lost." 37 The grants made in the charters to the Corporation of the city of New York derived their authority less from the references to "antient" practices than from the fact that those charters transformed preexisting claims into rights held by the city in fee simple absolute, the absolute property of the Corporation. ${ }^{38}$

${ }^{35} \mathrm{Id}$.

362 Colonial Laws, 591.

37 Thompson, supra note 32 , at 348.

38 For example, the waste and vacant land of Manhattan Island, first granted to the city in the Dongan Charter of 1686 , became the "commons" of the city. But the grant of that vast 
The ability of property to determine the autonomy of a corporation rested, moreover, not on some timeless "essence" of corporateness; rather, it was fixed by the peculiar history of borough charters, franchises, and privileges in the last twenty years of the seventeenth century. In 1680 , Charles II began a campaign to change the face of Parliament by forcing the boroughs to return less whiggish representatives. The strategy adopted was to threaten an action quo warranto to compel the boroughs to come to court to defend themselves against charges of misuser of their franchises if they would not agree to terms with the crown. The lynchpin of this strategy, at least according to later "whig" historians, was the famous quo warranto action that was actually brought against the city of London, a seat of opposition sentiment. London would be compelled to return its charter to the crown, to give up all its chartered properties through the action; the case would "reduce the City of London to the status of a small village, . . . place its government entirely in its [the Crown's] own hands and . . . strip it of all rights and privileges." 39

In the short run, the strategy worked. Judgment was given for the crown (although the city never actually gave up its charter), and most other boroughs quickly capitulated and returned their charters to the crown. By early 1688 , however, a desperate James II was forced to issue "A Proclamation for restoring Corporations to their Ancient Charters, Liberties, Rights and Franchises." 40 And after the Glorious Revolution the arguments of Recorder Treby and Pollexfen for the London Corporation became enshrined as constitutional gospel.

The year 1688 "sanctified" the privileges of English boroughs by making them into unquestionable "vested rights." 41 In England this meant that borough officers might become increasingly corrupt in their use of corporate property and separate corporate rights in the wealth of the

\footnotetext{
"commons," extending over the greater portion of Manhattan Island, gave no use-rights in that land to the inhabitants of the city. The commons was considered part of the estate of the Corporation, as a corporation. Unlike some contemporary boroughs in England, freemen held no "right of common" - no right to pasture their animals, gather firewood, and so forth-as a privilege of their freemanship. See the examples collected by Frederick W. Maitland in Township and Borough 197 (1899). The common council, acting for the Corporation, managed its estate to the exclusion of any "common" rights; to the Corporation the commons was simply a large piece of real estate absolutely owned. And through the first seventy-five years of the eighteenth century the common council leased plots, prosecuted trespassers, and tore down encroachments, all to the end of conserving the value of the property. See 1 Common Council 403; 2 Common Council 97-98, 113, 127, 129, 258-59; 3 Common Council 229-30, 240-41, 245.

39 Jennifer Levin, The Charter Controversy in the City of London, 1660-1688, and Its Consequences 2 (1969); see also Michael Landon, The Triumph of the Lawyers (1970).

408 Howell's State Trials 1039, 1277-78.

41 Frederick W. Maitland, Trust and Corporation, in Selected Essays 217 (1936).
} 
community from any perceivable public purpose, yet remain beyond any form of central control. ${ }^{42}$ The central government responded by shifting much of the governmental responsibilities-the public services -of local government to statutory commissions and other derivative agencies, making boroughs as irrelevant as possible to the necessary processes of local government. But full intervention into borough life had to await the formulation of a conception of corporate personality that was not dependent on property rights, had to await the separation of the sanctified "connection between corporateness and privilege." 43

The language used in the Montgomerie Charter of 1730 must be regarded as a direct legacy of the charter controversies of the $1680 \mathrm{~s}$. The last five pages of the document declared that the Crown would never sue New York City in an action "quo warranto." The properties granted by the charter were held in fee simple absolute, beyond the reach of attacks for misuser; the city was free to use them as it pleased. Nor would other properties, however acquired and however used in the past by the Corporation, raise an action "quo warranto." 44 Indeed, one might argue that one purpose of the charter was to assure the autonomy of the city in the manner of an eighteenth-century English borough, as an institution whose properties were sacrosanct. "[B]y these presents," by the various grants of property contained in the charter, the charter drafters proposed to constitute New York City as "a free City of itself." ${ }^{45}$ Unlike London, the city of New York could never have claimed perpetual existence as a basis of legitimacy, for it had an identifiable point of origin. But it no longer needed to assert the "antient" quality of its privileges. In the wake of the Glorious Revolution, rights granted by the crown in a formal charter would be sufficient to make New York "a free city of itself.'

This is not to say that there were not important theoretical and practical limitations on the autonomy of the corporation. The charter should not be read as creating a complete blueprint for governance. In a variety of ways, the city of New York remained dependent on the provincial government. Two limitations in particular should be mentioned. The governor retained the right to appoint the mayor, and the provincial legislature was the only body capable of ordering direct taxation. In the first case one must presume that the retention of the power of appointment by the governor was consciously intended as a limitation on the autonomy of the city; indeed,

42 Consider, for example, the member of the Cambridge Corporation who thought, "that the property [of the corporation] belonged bona fide to the corporation and that they had a right to do what they pleased with their own." Maitland, supra note 38, at 12-13.

43 Maitland, supra note 41, at 217.

442 Colonial Laws 635-39.

4.5 Id. at 597. 
the petition of the common council to Montgomerie for a new charter in 1730 had specifically asked for the power to elect a mayor.

The second limitation presents a more ambiguous picture. On the one hand, it is hard to imagine a more direct denial of local autonomy than for central authority to retain absolute control of taxation. On the other hand, until the 1760 s direct taxation was only rarely used by the Corporation as a revenue source. ${ }^{46}$ There were only four occasions between 1731 and 1750 when the need for revenue was so great that city officials had to seek authorization from the legislature to lay a tax ${ }^{47}$ Rents and other corporate revenues were usually sufficient for the purposes of municipal governance, and we might guess that the existence of a "freely disposable income" from the properties it had been granted gave the Corporation concrete affirmation of its autonomous status within the province. ${ }^{48}$

Still, in many respects the city remained the "political child of the province." 49 Authorization to repair or build new streets always came from the provincial legislature, as did a variety of police regulations; ferriage rates and other rate structures were usually set outside the city. The Mayor's Court, which one might assume would have retained a separate style of decision making, by the 1730 s had become simply a court of common pleas for the city whose decisions and practices were largely indistinguishable from those of county courts elsewhere. ${ }^{50}$ It is not at all clear whether these restrictions on the autonomy of the city developed in opposition to the articulated interests of city officials. We might suspect that most of the legislation was passed at the instigation of the representatives from the city. There is in any case a growing recognition among historians of colonial New York political life that from the time that English control of the province was secured New York City dominated the political life of the province. ${ }^{51}$ Still, the government of the city was closely integrated with the general governance of the province, and the autonomy granted by the charter was always partial and incomplete.

The very political theory which joined property with political autonomy also placed limits on that joinder. Property gave a corporation the right to

46 George William Edwards, New York as an Eighteenth Century Municipality 197-99 (1917) [hereinafter cited as Edwards, Municipality].

472 Colonial Laws 1061-63; 3 Colonial Laws 158-62, 542, 619-20.

48 Maitland, supra note 41, at 20405.

49 Jacob Judd, New York: Municipality and Province, in Aspects of Early New York Society and Politics 2 (J. Judd \& I. Polishook eds. 1974).

so Herbert A. Johnson, The Advent of Common Law in Colonial New York, in Law and Authority in Colonial America 83 (George A. Bilias ed. 1965); see generally Select Cases of the Mayors Court of New York City (R. B. Morris ed. 1935).

51 See Robert C. Ritchie, The Duke's Province (1977). 
control its own affairs free of systematic external interference. But that autonomy was always derivative and dependent. Property rights did not justify disobedience. To the contrary, Locke had written "that every man that has any possessions or enjoyment of any part of the dominions of any government does thereby give his tacit consent and is as far forth obliged to obedience to the laws of that government, during such enjoyment, as anyone under it." 52 New York City may have been a "free city of itself," but it was "of itself" only in relation to those areas of governance defined by its property rights, and even there its dominion could never be severed from the intermittent interference of central authority.

On the other hand, the eighteenth-century chartered city of New York was not a municipal corporation, at least not as we would understand the term today. In his classic discussion of New York City as an eighteenthcentury municipality, George William Edwards wrote:

But we must remember that as an eighteenth-century municipality it was merely an agent of the provincial government, devised, as Goodnow aptly says, "for the discharge of those functions interesting the state government which demanded local treatment." It is therefore always necessary to be mindful of this dependent position of a municipal corporation as we view its relations to the provincial government. ${ }^{53}$

He was wrong. Intermittent intervention by the legislature did not define the nature of the Corporation. Property did. The property rights of the eighteenth-century city were not tangential to the nature of the institution. As defined and described in the Montgomerie Charter they were what constituted its corporate personality. Today we may know "perfectly well" how to distinguish governmental from nongovernmental in terms of the use and ownership of property, but in the eighteenth century our task would have been complicated by the peculiar presence of propertied "governmental" corporations like the Mayor, Aldermen, and Commonalty of the city of New York.

\section{Property and Governance in Prerevolutionary New York}

\section{A. The Business of a Corporation}

Earlier students of the institutional history of eighteenth-century New York have regarded the property acquired under the charters of the city as important only for the revenue it provided for the administration of city affairs. In so doing they underestimated the important role corporate property played in creating distinctive forms of municipal governance. Of

52 John Locke, The Second Treatise on Government, § 119.

${ }^{53}$ Edwards, Municipality, supra note 46, at 34. 
course the need for new revenue offers one explanation for the common council's decision to apply for new grants in a new charter in the $1720 \mathrm{~s}^{54}$ And the income from corporate property did assume a significant place in municipal finances throughout the prerevolutionary period: making taxes little needed until the 1750 s, keeping the tax rate low thereafter, and giving the city ready collateral whenever it needed to borrow funds. ${ }^{55}$ But the existence of a freely disposable income scarcely exhausted the uses of property in the life of the Corporation. As we have seen, the property granted by the city's charters legitimated and defined a sphere of local autonomy; property rights guaranteed the individuality of the city. The estate of the city also created a possibility of planning, growth, and innovation on a scale unavailable to unchartered and unpropertied local governments, a possibility at least partially realized in the practice of government in New York City. The relative autonomy created by the

54 During the decade prior to the reception of the Montgomerie Charter the revenue of the city declined from a high of 731 pounds in 1722 to an average well below 300 pounds. See David Valentine, Financial History of the City of New-York, from the Earliest Period, in Valentine's Manual of the Corporation of the City of New-York 506 (1859). And it was a perception that only a new charter could provide new revenue for the Corporation that seems to have spurred the common council to apply to the governor of the province. For more on this, see text at notes 88-90 infra.

55 The most complete and reliable account of the finances of the eighteenth-century city is in Edwards, Municipality, supra note 46, at 190-205. Edwards offers the following tale of the returns from the revenue-bearing properties and franchises of the Corporation:

Municipal Revenue from Franchises and Properties in Pounds, Over Five-Year Periods

\begin{tabular}{lrrrrrrrr}
\hline \hline & Ferries & Docks & Markets & Lands & Waterlots & Buildings & Licenses \\
\hline $1730 \ldots$ & $£ 246$ & $\ldots$ & $\ldots$ & $£ 28$ & $\ldots$ & $\ldots$ & $£ 91$ \\
$1735 \ldots$ & 243 & $\ldots$ & $\ldots$ & 5 & $£ 33$ & $£$ & 2 & 89 \\
$1740 \ldots$ & 307 & $£ 73$ & $\ldots$ & 7 & 65 & 2 & $\ldots$ \\
$1745 \ldots$ & 370 & 90 & $£ 105$ & 7 & 68 & 2 & 194 \\
$1750 \ldots$ & 455 & 110 & 159 & 7 & 99 & 5 & 180 \\
$1755 \ldots$ & 650 & 305 & 190 & 40 & 142 & 50 & 172 \\
$1760 \ldots$ & 650 & 500 & 245 & 122 & 196 & 50 & 524 \\
$1765 \ldots$ & 800 & 550 & 385 & 501 & 225 & 100 & 180 \\
$1770 \ldots$ & 970 & 690 & 250 & 374 & 460 & 60 & 230 \\
\hline
\end{tabular}

Id. at 191. (Slightly different figures for 1740 may be found in Valentine, supra note 54, at 507.)

Although Edwards argues the case for the growing dependence of the city on tax powers that could only be delegated by the provincial legislature, even he concedes that, "For many years the returns from the revenue-bearing properties and franchises of the corporation were barely sufficient to meet expenses." Id. See also Edward Durand, The Finances of New York City 7-40 (1898); George Ashton Black, Municipal Ownership of Land on Manhattan Island (1891); and Sidney I. Pomerantz, New York: An American City 1783-1803 (2d ed. 1965). 
Montgomerie Charter and its predecessors was not meant simply as protection from external interference; it also bestowed a freedom to act. In effect, the charter constituted a license to initiate change, a liberation from the commitment to a consensually determined status quo that characterized most local government in provincial America. ${ }^{56}$ The property rights granted in the Montgomerie Charter were granted in pursuit of the goal of creating a major seaport in New York City. In protecting the Corporation of the city of New York from the harm of externally imposed change, the charter also laid the basis for internally instituted innovation.

This position would sharply separate the institutional history of eighteenth-century New York City from two major interpretations of the history of the American city. One interpretation, closely identified with the writings of Sam Bass Warner, asserts that the history of the American city has always been shaped by a culture of privatism. American cities were the products not of community planning or public initiative but of the individual decisions of individualistic Americans. "[T]he physical forms of American cities, their lots, houses, factories, and streets have been the outcome of a real estate market of profitseeking builders, land speculators, and large investors." 57 Government has always been inadequate; indeed, it usually has been irrelevant to the main processes of growth and change. According to Warner, even before the Revolution the sphere of public action was limited and separated from the economic life of the American city.

By contrast, another interpretation, one most recently restated by Jon Teaford, views the early American city as a reflection of the regulatory traditions and practices of the medieval English borough. The chartered corporation was introduced into the colonies as a way of controlling and fostering commercial life. Until the Revolution, American city government-with the exception of the unchartered "town" of Boston-had no proper sphere of activity but the regulation of economic activity. ${ }^{58}$

These two interpretations offer dramatically different perspectives on our urban past. ${ }^{59}$ They converge, however, in their general picture of

\footnotetext{
56 See Part II-C infra.

${ }^{57}$ Sam Bass Warner, The Private City: Philadelphia in Three Periods of Its Growth 4 (1968).

58 Jon Teaford, The Municipal Revolution in America (1975). One finds here strong echoes of the perspective of the authors of the institutional studies of urban government that flourished in the early twentieth century. See, for example, Robert Francis Seybolt, The Colonial Citizen of New York City (1918), subtitled, A Comparative Study of Certain Aspects of Citizenship Practice in Fourteenth Century England and Colonial New York City.

59 According to Teaford, the postrevolutionary era witnessed the triumph of a "public welfare" theory of urban governance which entirely eclipsed the earlier commercial focus of the premodern chartered corporation. Warner, more pessimistic, argued that there is a
} 
mid-eighteenth-century urban governance. According to Teaford, the spread of libertarianism during the middle years of the eighteenth century weakened the regulatory control of municipal corporations and necessitated a partial withdrawal by urban authorities from their traditional fields of primary authority. In a few cases their attention shifted to newer areas of health and safety regulation and public works. But in other cases, municipal corporations "reacted to change with lethargy and indifference." 60 The middle of the eighteenth century should, therefore, be regarded as a transitional period when urban government was separated from an increasingly private market economy but had not yet fixed on a modern conception of its role in urban life.

Warner undoubtedly would agree with that characterization of eighteenth-century practice, although for him the absence of a proper public role is a more or less permanent feature of American cities. The Philadelphia of Revolutionary America that is his model of a "private city"' had

a regime of little government. Both in form and function the town's government advertised the lack of concern for public management of the community. The municipal corporation of Philadelphia, copied from the forms of an old English borough, counted for little. . . .

By modern standards the town was hardly governed at all. ${ }^{61}$

To both Teaford and Warner the chartered corporate governments of early modern America were fast becoming-or had already becomeanachronisms irrelevant to the communities they were presumably intended to serve.

Philadelphia provides the model of eighteenth-century corporate government for both Teaford and Warner, and they may have correctly identified features of Philadelphia's corporate life that typified eighteenth-century American municipal behavior generally. In several respects, however, the government of New York City was very different from that of Philadelphia. New York's Corporation remained inextricably identified with the city it was chartered to govern. While the "close" corporation of Philadelphia effectively excluded most residents of the city from participation in its affairs, the Montgomerie Charter made the Corporation of New York into a classically "open" organization. Anyone might be admitted as a freeman, as a politically active member of the Corpora-

\footnotetext{
depressing continuity in America urban history defined by our continuing commitment to a culture of privatism. A moment's reflection suggests the truism that both positions might be-and probably are-equally true as perspectives on our urban past.

${ }^{60}$ Teaford, supra note 58 , at 56.

61 Warner, supra note 57, at 10.
} 
tion. ${ }^{62}$ In 1731 the cost of becoming a freeman of the city was set at three pounds for merchants or shopkeepers and twenty shillings for craftsmen, but the common council could and did grant the privilege gratis to any resident who could not pay. ${ }^{63}$ The result was that in New York City "the Commonalty" of the Corporation became in effect the entire populace of the city, or at least the white male populace, while in Philadelphia "the Commonalty" of the Corporation was a distinct community, a particular identifiable elite, within the larger city.

Throughout the eighteenth century, moreover, the Corporation of New York remained the government of all aspects of city life subject to public control. Unlike what was the case in Philadelphia, there were no statutory authorities in New York. Even most voluntary associations were under Corporation sponsorship. Where public action was necessary, it occurred under the auspices of the Corporation, or it did not occur at all. And well into the nineteenth century New Yorkers could speak of "our Corporation" when they referred to the government of their city. ${ }^{64}$ The separation of government from corporation that seems to have characterized eighteenth-century Philadelphia occurred much later in New York City.

The issue is not, though, the marginal differences between Philadelphia and New York City. The issue is how one ought to evaluate the utility and effectuality of corporate government in eighteenth-century America. Was New York City "a regime of little government" like Warner's Philadelphia, or was it rather a regime whose government can only be understood if we put aside our conventional expectations about the nature of a public sphere?

Teaford has used what he calls a "content analysis" of ordinances to argue that there was a moderate decline in the concern with commercial regulation in cities throughout provincial America. By his calculations, where 54 percent of New York City's ordinances dealt with trade or commerce in 1707 , only 47.6 percent did so in $1773 .{ }^{65}$ But all forms of legislative activity-and ordinances in particular-have weaknesses

62 Milton Klein, Democracy and Politics in Colonial New York, in The Politics of Diversity: Essays in Honor of Colonial New York 20-25 (Milton M. Klein ed. 1974), Beverly McAnear, The Place of the Freeman in Old New York, 21 N.Y. Hist. 418 (1940).

63 4 Common Council 96-97; for the equivalent rates for 1702 and 1751 see 2 Common Council 198-99; and 5 Common Council 326.

${ }^{64}$ See Charles E. Rosenberg, The Cholera Years 17 (1962).

This is not to deny that eighteenth-century New Yorkers could distinguish their individual interests from that of the Corporation whenever the two diverged. When Cornelius Sebring applied to the crown's officials for a grant of a competing ferry, prior to the grant of the ferry franchise in 1708 , his petition was accompanied by a supporting letter from a number of residents of the city. 3 O'Callaghan, supra note 34, at 256.

${ }_{65}$ Teaford, supra note 58, at 18-52. 
when used to define the corcerns of a governmental institution. ${ }^{66}$ Teaford's statistics in fact unquestionably understate the disinterest of the midcentury common council of New York City in commercial regulation. If one looks at the minutes of the council, the record of its ordinary activity, it becomes apparent that trade regulation consumed a miniscule proportion of the worktime of the council. Of some 97 entries into the minutes in 1737, no more than 9 can in any way be characterized as dealing with the regulation of trade and commerce, and in the case of 4 entries it is unclear whether the measures ordered by the council were intended to achieve goals of the promotion or control of economic life in

66 Teaford's expectation that an analysis of the subject matter of ordinances would reveal the nature of a corporation is, I think, fundamentally flawed as a research strategy:

(a) Legislative activity is inherently ambiguous. Is legislation passed because legislators feel the need to act in a particular area or is legislation passed as a substitute for action, as a form of symbolic politics? The fact that Philadelphia passed almost no new ordinances between 1740 and 1776 might stand as easily as evidence for the effectiveness of its regulatory structure as for Teaford's presumption of a quiescent government. There is moreover no way from Teaford's narrative to learn anything about enforcement patterns. Is legislation passed because it is expected to validate ideological presuppositions of what a municipal corporation ought to be doing? It might be, in fact, that the by-laws of the corporations Teaford has studied reveal the survival of an archaic ideology of a commercial community long after the actual practice of local government in those communities has changed in rather dramatic ways.

(b) Even on its own terms there is reason to question Teaford's statistics. His tables represent a "title" or subject matter analysis of corporate by-laws rather than a "content analysis." He assumes that titles of ordinances reflect the content of those ordinances, but in eighteenth-century New York City that was certainly not the case. What New Yorkers referred to as the "nuisance" ordinance was entitled, "A Law for paving and cleaning the Streets, Lanes and Alleys within the city of New-York, and for preventing Nuisances within the same." By 1763 it had seventeen sections, including rules on disposal of manure and offal, wages for cartmen, restrictions on the location of tanneries, dyers, starchmakers, and slaughterhouse, ("because the Health of the Inhabitants of this City, does in a great Measure depend upon the purity of the Air of that City"') as well as a prescription of the dates during which shellfish might be sold in the city. New York City legislators had not yet "learned" the modern rule of legislative drafting that there should be only a single subject for each title of legislation. The number of by-laws passed in particular areas of concern probably does not reflect the actual incidence of attention by the Common Council. And the percentages Teaford gives may bear no relationship to the actual content of legislation. It appears, for example, that most trade regulation by-laws consisted of a single section. If one factored in the disparate sections of the nuisance ordinance and of other public regulations, the percentages of his tables would have been very different. Public or health regulation might have seemed at all times a weightier part of the business of the corporation. What is a law is an unavoidable question for anyone who writes legal history.

(c) Finally, reliance on ordinances creates the false impression that the proper business of a government is necessarily some form of regulation. For Teaford the history of the municipal corporation in America is one of the choice between trade regulation and health and safety regulation. But it is equally possible that government might be concerned with different questions or, more precisely, might be pursuing governmental ends through nonregulatory techniques. Teaford's methodology forces him to consider that which is nonregulatory in the affairs of an eighteenth-century city as almost necessarily nongovernmental. 
the city, or were intended for some other governmental purpose ${ }^{67}$ Similarly, in 1767 only 11 of 157 entries had anything to do with commercial regulation. ${ }^{68}$

Indeed, we may wonder if the "medieval" notion of a city as an exclusive, monopolistic, commercial community had any legal significance in the life of the Corporation of the city of New York after the reception of the Montgomerie Charter. The members of the common council made no attempt to preserve city trade for city residents, much to the dismay of local retailers-particularly butchers and fresh produce vendors-who felt victimized by the "Country People who rented stalls in city markets and undersold the local competition. ${ }^{69}$ Consider also the oath given to newly admitted freemen. In 1707 the common council had authorized a version which closely paralleled a fourteenth-century oath used by the corporation authorities of the city of London. ${ }^{70}$ Among other things it ordered the new freeman to warn the mayor whenever he heard of "Forreigners"' (or nonresidents) buying or selling within the city boundaries, forbade him from suing any other freeman of the city in a court outside of the city, and prescribed the terms under which he would take and care for apprentices. ${ }^{71}$ In 1731 , after the reception of the new charter, the council drew up a new oath which eliminated all references to the commercial life of the city and to the particular significance of city boundaries in establishing a commercial community. ${ }^{72}$ The city as a government was separated from the older perception of a city as an economic unit. And this latter version remained the "oath" of the city throughout the prerevolutionary period.

There remained throughout this period a rhetorical identification of the Corporation with the commercial life of the city. ${ }^{73}$ Petitions to the com-

674 Common Council 361-410.

687 Common Council 51-105.

69 See the Petition of Israel Harsfield, Timothy Harsfield, Richard Green, and other Butchers, in Petition File, 1735 (N.Y. Municipal Archives and Records Center (MARC)). The solution offered by the common council was to give resident butchers a discount rent to their market stalls.

One reason why the city stopped trying to exclude nonresidents from the economic life of the city was that a growing number of residents depended on the trade of the nonresidents. Whenever restrictions against country people were too stringent, there would be complaints that the regulation depressed business. See Petition of Francis Koffler, an innkeeper who farmed the ferry, Petition File, 1766.

70 Seybolt, supra note 58.

71 N.Y. Historical Society, Collections 460-61 (1885).

724 Common Council 121.

${ }^{73}$ See Petition of Sundry Persons dwelling and residing and being owners of the Houses and Lots of Ground near and adjacent to Burling's Slip, Petition File, 1766; see also Petition of the Inhabitants of Crown Street, Petition File, 1767. 
mon council continued to ask for varieties of commercial franchises and privileges, which usually were justified by reference to the commitment to commercial growth that was said to unite the members of the Corporation. ${ }^{74}$ And as Teaford suggests, there are some indications of a new rhetorical concern for public health and safety regulation in the records of the period. ${ }^{75}$ Still, the desire for regulation-whether public health related or commercial-should not be exaggerated. Questions of "public," noncommercial regulation were raised no more frequently before the common council than were questions of commercial regulation. In both 1737 and in 1767 the minutes of the council record only nine entries that were even arguably concerned with health and safety.

It is clear that by 1730 the Corporation of the city of New York could no longer be defined as the embodiment of a commercial community. But neither was it a public welfare agency on the order of a nineteenth-century municipal corporation. What, then, was its proper business? How may its concerns be described?

From the perspective of the citizens of the city who petitioned to the Corporation the answer was unmistakable. The proper business of the Corporation was the management, care, and disposal of its real estate. Approximately 60 percent of the petitions sampled between 1730 and 1770 concerned the property rights of the Corporation. Between 1765 and 1767 the figure rose to nearly 75 percent. Petitioners petitioned for abatement of their rents to the Corporation, ${ }^{76}$ for a new lease, ${ }^{77}$ for a right to farm the ferry. ${ }^{78}$ The Reformed Protestant Dutch Church asked for a lot in the commons because their present cemetery was full. ${ }^{79}$ Merchants and others would on occasion ask permission to clean or improve or repair or "encroach" on some piece of city property, usually a pier or a slip. ${ }^{80}$ Most of all, petitions to the common council revolved around requests to the Corporation for grants of waterlots, grants of the land under water surrounding the settled part of the city up to 400 feet beyond low water mark.

${ }^{74}$ See Petition of Cornelius Van Vorst, Petition File, 1765.

75 See Petition of Joseph Simson, Petition File, 1755.

${ }^{76}$ Petition of Francis Koffler, Petition File, 1766.

${ }_{77}$ Petition of John Kelly (slaughterhouse), Petition File, 1736; Jocobus Rickman (room in Commons for Brick Kiln), Petition File, 1747; Petition of Isaac Delameter (small house), Petition File 1756; Petition of Nicholas Bayard (slaughterhouse), Petition File, 1767.

78 Petition of Cornelius Van Vorst, Petition File, 1766.

79 Petition of the Minister et al. of the Reformed Protestant Dutch Church, Petition File, 1766; see also the Petition of the Minister et al. of the English Presbyterian Church, Petition File, 1766.

80 Petition of William Comell, lessee of ferry, Petition File, 1737; Petition of sundry individuals living near Clarke's Slip, id.; Petition that the encroachment made by Robert Munro on the slip may be permitted to continue, as it is more convenient, Petition File, 1766. 
Petitioners "inclined to make considerable improvements" 81 to those waterlots asked for grants on terms discussed in detail in the next section. But petitions for waterlots were frequently followed by counterpetitions attempting to dissuade the council from making a particular grant to a particular individual or set of individuals. Counterpetitions might argue that the Corporation was violating its own customary procedures for making grants, "That the Custom and Practice of this Corporation with Respect to granting their Water Lotts, so far as the Petitioners are Acquainted therewith, has ever been to give the preference to those, who held the Lotts fronting the River." 82 Or the counterpetition might set out a claim of title in theory superior to that of the original petitioner(s). ${ }^{83}$ The point is not that these petitions should determine our sense of the nature of the eighteenth-century Corporation. Rather these petitions demonstrate what part of the business of the Corporation provoked the interest-more precisely, the self-interest-of its citizens. ${ }^{84}$ It was the property of the Corporation, not its economic regulatory powers nor its public-welfare regulatory powers, that claimed the attention of eighteenth-century New Yorkers.

The minutes of the common council also reflect a continuing preoccupation with the management of the corporate estate. In both 1737 and in

81 See Petition of Jacob Brewerton, Petition File, 1765. See also the petition of Elizabeth Richards and others, who presented on May 22, 1761:

". . . that their houses front that part of the East River Commonly called Hunter's Bay which was become a great Nuisance by the Settlement therein of all kinds of Garbage, Filth and Dirt ... and that the water between the East and West Piers is become so shallow as to render the same useless and greatly detrimental to the Health of the Petitioners . . . and therefore conceived that the filling up the same Water Lots would greatly add to the Ornament of the City as well as the conveniency of the Harbor, prayed that the said Mayor Aldermen and Commonalty would be favourably pleased to grant to them the said water lots so far into the said East River as the Present Wharfs on the East and West sides extend under such reasonable rents etc. as should be thought fit and reasonable."

Elizabeth Richards was one of several active women merchants who actively sought and secured waterlots in the mid-eighteenth century. See the Corporation Grant to Elizabeth Sharpas, spinster, August 23, 1939, Grant Book B (MARC); see also Jean P. Jordan, Women Merchants in Colonial New York, 58 New York History 412-39 (1977).

82 Petition of Owners of lots in Montgomery and Out Ward, Petition File, 1765. There were, on the other hand, limits to the kinds of protests the council would entertain. Mr. Brownjohn protested against the Corporation appropriating a waterlot fronting his lot for the use of a slip, to which the Council responded, "this Board conceiving the same to be an insolent and impertinent paper did thereupon unanimously resolve and ORDER that the same be thrown under the table and the same is thrown under the table accordingly." 7 Common Council 27 (1766).

83 See the various petitions protesting the waterlots proposed to be distributed in "rotten row" in 1766. Petition File, 1766.

${ }^{84}$ See also the controversy over waterlots in 1753 conducted in the Independent Reflector 118-27, 151-56 (Milton Klein ed. 1963) [hereinafter cited without cross reference as The Independent Reflector]. 
1767, property decisions were much the most important substantive area of council concern. If we ignore the routine, nondiscretionary business of the Corporation (entries into the minutes for warrants to the mayor to pay the accounts and the salaries owed by the Corporation, entries warranting tax collections and auditing accounts, and entries for certification of elections and the swearing in of officers), it is evident just how important the corporate estate was in the work of the Corporation. In 1737 fully one-third of all the discretionary entries in the minutes dealt with property owned by the Corporation; in 1767 nearly 50 percent of these entries were concerned with the management of the corporate estate. Neither trade regulation nor public (noncommercial) regulation or other action ever constituted more than 20 percent of the business of the council in these years. If the minutes of the common council are to be believed, it was the concerns of a property owner that best defined the business of the Corporation of the city of New York.

This description of the Corporation at first glance may seem very similar to Teaford's picture of Philadelphia in the years prior to the American Revolution. His Philadelphia was a city government that "neglected both the traditional tasks of trade regulation and the newer duties of safety and public works" in order to concentrate its efforts on managing corporate properties. $^{85}$ In so doing, according to Teaford, the Corporation of Philadelphia ignored its governmental responsibilities. Likewise, we might say, the Corporation of the city of New York, as the government of the city, devoted an inordinate amount of time to its corporate-its private-property. But in New York that "obsession"' with corporate property did not lead to a separation of the concerns of the community from those of the Corporation. A paradox? Why should New Yorkers have regarded as their legitimate government an institution whose attention was firmly fixed on its own private property interests?

One could argue either that New Yorkers of the time wanted a lethargic and neglectful government, or that it is we and not the Corporation of the city of New York that have neglected its true governmental functions. Both positions may be true. It may be that New Yorkers preferred a city in which individuals were dependent on their own resources, preferred at least a version of Warner's "private city." But without losing sight of the commitment of city leaders to private economic growth, it is the other perspective that demands our attention here, one that views the management of a corporate estate as a mode of public planning and governance. Such a perspective insists that we put aside later assumptions as to the irreconcilability of property concerns with governmental action and of

\footnotetext{
${ }^{85}$ Teaford, supra note 58 , at 56.
} 
what constitutes the proper business of a public institution. The Corporation of the city of New York spent most of its time managing its property; yet it remained the government of the city. ${ }^{86}$ What we need to understand is how property offered the city of New York a legitimated structure of action within the constraints of Anglo-American political and legal theory.

\section{B. Planning by Granting}

In the 45 years between the reception of the Montgomerie Charter and the beginning of the American Revolution, disposing of the waterlots of the lower city was unquestionably the dominant property-related concern of the officers of the Corporation. ${ }^{87}$ Indeed, insofar as property management properly characterized the government of the prerevolutionary city, a waterlot grant perhaps should be regarded as an appropriate symbol of that government. The waterlots were the only new parcel of property granted to the city under the 1730 charter, and it appears that their absence was the main reason why the members of the common council decided to seek a new charter in the 1720s. The first time the "need" for a new charter was mentioned in the minutes of the council was in $172 \overline{2}$ after Gerritt Vanhorne had petitioned the Governor of the province for a grant of "all the land that may be Gained out of the East River [between Maiden Lane Slip and the end of Wall Street] . . to extend to the Said River two hundred foot with Liberty to Erect Buildings, Cranes, Stairs, etc. And to Receive the Profits and Wharfage thereof.' The Common Council remonstrated to the Governor as to "the great prejudice the Granting thereof may be to the Publick in General and this Corporation in Particular,' and then decided that it had better itself petition for a new charter that would include a grant of all the land that might be gained out of the harbor, plus "Such other Privileges Franchises and Immunities as are Usually Granted to Cities and Towns Corporate in England.'"88 In every

\footnotetext{
${ }^{86}$ In demonstrating that public purposes shaped the management of New York's corporate estate, all that might be shown is the exceptionality and isolation of New York City within the world of eighteenth-century local government. It is possible that New York's Dutch heritage separates the history of New York City from the rest of provincial America. See Jan de Vries, Barges and Capitalism: Passenger Transportation in the Dutch Economy, 1632-1839, in 21 Afdeling Agrarische Geschiednis (Wageningen), Bijdragen 33-398 (1978). But historians of English local government also stress the importance of corporate property in the life of eighteenth-century municipal corporations. For a case study of a relatively "activist" use of property see the discussion of Liverpool in Francois Vigier, Change and Apathy (1970). The other, more common image of corporate lethargy and quiescence is presented in R. W. Greaves, The Corporation of Leicester 1689-1836 (1970); and Malcolm I. Thomis, Politics and Society in Nottingham, 1785-1835 (1969).

${ }^{87}$ See, for example, 4 Common Council 25-211, for the years 1731 to 1734

88 3 Common Council 271-78. The origins of this conflict begin in 1720, 3 Common Council 221.
} 
petition thereafter to the royal authorities the waterlots headed the wish list of the Corporation. ${ }^{89}$ And as soon as the new charter was secured and confirmed, the council set about the difficult business of granting away the lands under water and the right to develop the emerging waterfront of the growing city. ${ }^{90}$

Still, it might seem that a waterlot grant is a peculiar focus for a discussion of the uses of a corporate estate in planning and governance. One might in fact suspect that the process of disposing of the most valuable property owned by the Corporation at nominal quitrents ought rather to be regarded as the antithesis of active governmental planning. The disposal of the waterfront of New York City bears a suspicious resemblance to the disposal of the public domain by the federal government during the nineteenth century, which, as every student of American history knows, delivered up the development of the West to private speculator control. And students of the history of New York City have usually judged the waterlot grants made by the eighteenth-century Corporation in similarly harsh terms, when they regarded them at all. John W. Reps, the leading historian of American city planning, sees eighteenth-century New York City as a prime example of an unplanned city. ${ }^{91}$ George W. Edwards concluded that the city acted "with utter disregard for the future" in allowing its rich riparian rights to fall into the hands of private individuals. ${ }^{92}$ Another historian speculates that "perhaps the government simply anticipated New York's growth by abandoning in advance any influence over it. ${ }^{93}$

Historians have often viewed these grants as typifying the corruption of the Corporation-an earlier version of the shame of the city ${ }^{94}$ Relying on a 1753 '"exposé" in William Livingston's Independent Reflector they have concluded that waterlot grants were nothing but a series of "shady land deal[s] by which some local business- men, in collusion with the City

89 Common Council 5-8, 19-22.

90 The centrality of waterlots in the plans of the Corporation is underscored by the fact that in 1730 Van Horne was bribed to withdraw his petition to the Governor with a promise that when a new charter was obtained he would get a 400 -foot lot instead of the 200 -foot lot he had petitioned for. See 4 Common Council 25. The promise was fulfilled in 1734. 4 Common Council 211. See also Corporation Grant to Cornelius Van Horne, July 26, 1734, Grant Book B (MARC). It appears that Van Horne was the only grantee throughout the prerevolutionary period to receive a lot that extended more than 200 feet into the river.

91 John W. Reps, The Making of Urban America 150-54 (1965).

92 Municipality, supra note 55, at 150 .

${ }^{93}$ Josef W. Konvitz, Cities and the Sea: Port City Planning in Early Modern Europe 65 (1978).

${ }^{94}$ Edwards, Municipality, supra note 46, at 150-51; Milton Klein, Introduction, to The Independent Reflector 30; Carl Bridenbaugh, Cities in Revolt 39 (rev. ed. 1970). 
Council, planned to get valuable shore- line property for a song." 95 letter with commentary in that paper revealed a series of transactions by which council members themselves were to receive grants to waterlots at a low consideration without public bidding, on the assumption that because the council members owned the lots fronting the waterlots they therefore owned the preemptive right to purchase these waterlots whenever the city decided to convey them. As Livingston noted, it was "incredible" that a majority of the council "should join in so iniquitous a Concession." After all, "Does Contiguity of Land infer a Right?'" The business of making waterlot grants was nothing but an institutionalized abuse of power, a way for corrupt council members to "lavish, in manifest Violation of their Trust, the Property of the City, to enrich and gratify a few Individuals." 96 To label it a form of city planning would be to rob language of meaning.

Yet one may wonder. Those historians who have allowed the Independent Reflector to shape their vision of the waterlot grants appear not to have read the grants themselves. Neither have they considered the significance of a later issue of the Independent Reflector in which a correspondent argued that the situation revealed in the earlier issue was not an exceptional abuse of power.

But further, Sir, excepting a few Instances, it has invariably been the Practice of the Corporation, to grant the Water Lots to particular Petitioners, upon Terms agreed on between them, and not at Vendue [public auction]. In these Grants, the Preference has generally been given to the Proprietors of the Upland, contiguous to the Water Lots. ${ }^{97}$

Livingston responded that although he would concede that perhaps the petitioners were not acting improperly in relying on a "common Practice," still they had "no more Colour for pretending, that the Contiguity of their Lands, entitles them to what belongs to the City, than to the Lands of any adjoining Neighbors." The expectations created by a common practice did

indeed place the Conduct of the Petitioners in a more favourable Light; but render that of the Corporation . . . the more inexcusable and unjust. Have former Corporations made a Practice of giving the Lands of the City, it should be an Inducement to their Successors, to obliterate the Remembrance of those Transgressions, by a more inviolable Attachment to their Duty. ${ }^{98}$

Looked at from the twin perspectives of whig political theory and of a

${ }_{95}$ Klein, Introduction, to The Independent Reflector 30.

${ }^{96}$ The Independent Reflector 124.

${ }^{97}$ Id. at 153 .

${ }^{98} I d$. at 155 . 
"Blackstonian" theory of exclusive property rights Livingston was clearly correct in his general condemnation of the conduct of the Corporation. ${ }^{99}$ But neither whig political theory nor a theory of property rights founded on the absolute power of a possessor to exclude accurately reflected the legal world of eighteenth-century New York City. ${ }^{100}$ Whether or not waterlot grant petitioners ought to have presumed that contiguity created a legitimate interest in the real estate of the city, those with land fronting waterlots certainly did make such a presumption. In their view, sale by public auction would have constituted a deprivation of their own property rights. Practically every successful petition for a waterlot grant was premised on the fact that the petitioner's land fronted on a waterlot. ${ }^{101}$

A long petition to the common council in $\mathbf{1 7 6 5}$ put the case forcefully for the propriety of a practice of private sale. Those who owned land fronting the East River, wrote the petitioners, have looked upon their right to purchase the contiguous waterlots as a practice of "long and almost invariable usage and custom:"

[They] have been so far enfluenced by that Consideration, as to look upon it, like a Sort of unalienable Priviledge belonging to their Estates, and hence in their Transfers from one to another, the Price and Value of those Estates, has been by that means, proportionally increased.

The petitioners insisted that they did not mean to imply that the Corporation was "bound never to depart from a rule of this Kind;" they did, however, insist that the council should "be tender of the Rights of Individuals" when the effect of deviating from the "rule" would be to "diminish the Value of every Estate that is now held, under this particular Circumstance."'102

In effect the petitioners argued that they had a property interest in the water rights owned by the city, perhaps on the order of the right every property owner has to prevent the existence of a nuisance on his or her neighbor's property, or a right of first refusal. But we should be careful not to make this expectancy interest appear more precise than in fact it

99 See Klein, Introduction, to The Independent Reflector 1-50.

100 Nor should it be seen as a direct and accurate reflection of the legal world of eighteenth-century England. See E. P. Thompson, Whigs and Hunters (1976); id., supra note 32, at 328-60; Daniel Boorstin, The Mysterious Science of the Law (1941).

101 Where it didn't, a grant of a waterlot was preceded by a grant of the contiguous land. See for example the Release of Lot . . . to Anthony Rutgers, July 24, 1766, Grant Book C (MARC) (of the land between high and low water mark) followed immediately by a Corporation Grant of the waterlot. Id.

102 Petition of Sundry Persons Owners \& Proprietors of Lotts of Ground situate in Montgomery and the Out Ward of the City of New York-fronting the East River, Petition File, 1765 
was. The Corporation had the power to appropriate a waterlot to public uses-such as a public slip or dock-without offering any compensation to the contiguous owner. ${ }^{103}$ Moroever, if the owner of the frontage was unable or unwilling to take the waterlot on the terms set by the Corporation, the common council might transfer the right in the waterlot to another, perhaps at public sale. ${ }^{104}$ Indeed, it appears that the owner of the frontage owned nothing personally; the interest was appurtenant to the land he or she held. Even the petitioners quoted in the previous paragraph conceded that their "priviledge" was inalienable and belonged to their estates. ${ }^{105}$

It is impossible to say whether the process of making waterlot grants was corrupt or not. It is difficult even to decide what it would have meant in the context of the general political culture of eighteenth-century New York to call the process corrupt. ${ }^{106}$ We can assume that waterlot grants were usually made to the rich and powerful of the city who in many cases were also members of the common council. Still, the obligations imposed through the terms of those grants were so severe as to make it unlikely that anyone but a relatively rich person would have had any interest in receiving a waterlot grant. More important, even a "corrupt" process may succeed as a planning tool. The problem of governance that the granting process was designed to solve was how to expand and develop the port facilities of the city. To understand how waterlot grants effected goals of commercial expansion and growth, we shall have to put aside juridical questions of the guilt or innocence of corporate grantees and corporate officers and look to the grants themselves: what they conveyed away from the city and what they required of the grantees. ${ }^{107}$

${ }^{103}$ See entry 7 Common Council 27 (1766). Two petitions from the file of 1766 revealed the fears of some individuals that if all the waterlots were granted away in Rotten Row (which was being developed at that time) there would be no place left for any "public edifice" - for an exchange or a market; both petitions asked that the common council reserve space for the use of the public.

104 See 4 Common Council 212 (1734), where the common council acted on the petition of Jacob Goelet and Abraham Van Wyck, the executors of André Teller. They had petitioned for and been granted a waterlot for the use of Teller's daughter. The grant had included a covenant for "Docking Out the same within a Certain Limited time, which Neither the Said Child nor we the Executors are Capable of performing." And the "privilege" of the grant was transferred to Stephan Bayard.

105 Petition File, 1766.

106 See Stanley N. Katz, Newcastle's New York (1968).

${ }^{107}$ The following discussion of the provisions of the waterlot grants conveyed by the Corporation is based on a reading of all copies of the grants held by the New York Historical Society (NYHS) (about 50 in number) and a more selective examination of grants from the official Grant Books (primarily from Books B and C) held in the Municipal Archives and. Records Center (MARC). All grants of the Corporation, including those found in the New York Historical Society, were recorded in full in the Grant Books of the Corporation (A through $F$ ) and can be found arranged in chronological order. 
During the prerevolutionary period waterlots were granted out at intermittent and irregular intervals. In 1772 the Corporation made 29 waterlot grants. In five other years, 15 or more grants were made. But most years the number of grants never exceeded three. ${ }^{108}$ Usually grants were made to groups of neighboring landowners. Either the city waited for such a group of neighbors to come forward with a plan for the development of a particular part of the waterfront, or the Corporation developed a plan and then solicited petitions for grants from contiguous landowners, or the process involved elements of both alternatives. Without more research into the real estate concerns and plans of the city's commercial elite, it is impossible to say where the original impetus for making the grants came from. ${ }^{109}$ In any event, the process culminated in a grant which both memorialized the agreement between the Corporation and the grantee and constituted the conveyance of the waterlot. The conveyance was recorded in a "Grant Book" of the Corporation, and the grantee received title to the land lying under the water of his grant.

Typically, a grantee received a lot that extended 200 feet into the East River"10 from "low water mark" "11 or (what was usually the same thing) the border of the grantee's own lands. The breadth of the waterlot was determined by the breadth of the grantee's frontage and ranged from a low of 16 feet $^{112}$ to a high of 116 feet. $^{113}$ Along with title, grantees uniformly received the eventual right to charge rent for the use by merchants and shipowners of the docks, wharves, and piers that would be constructed on the lot. It was this potential rental value-the right to collect dockage, wharfage, pierage, slippage, cranage, and so forth-that constituted the main incentive to apply for a grant. Every conveyance of the city's waterlots hinged on the transfer of the "profits and advantages" that were appurtenant to the lots.

Quitrents for these grants, payable annually on March 25, could be as little as one peppercorn or as much as eight pounds, five shillings. In general the amount of the quitrent was figured on an equal per foot of breadth rate for all grants made in a particular area at a particular time,

108 See the "Location Index" in Corporation of the City of New York, Indexes to Water Grants, 1686-1904 (manuscript at MARC).

${ }^{109}$ There is nothing in Virginia D. Harrington, The New York Merchant on the Eve of the Revolution (1935), on speculation in city lands. For a later period see 2 Kenneth Porter, John Jacob Astor, Business Man 910-52 (1931).

110 Until after the Revolution relatively few grants were made along the Hudson because of the fear that ships moored along its docks might be damaged by ice floes.

111 In the wake of the Dongan Charter of 1686, the Corporation had granted away most of the lots between high and low water marks which had as a result been filled in. "Low water mark" thus often meant the end of a lot bordering on the river.

${ }_{112}$ Corporation Grant to T. Jeffreys, April 19, 1735, Grant Book B (MARC).

${ }^{13}$ Corporation Grant to S. Farmer, July 24, 1766, Ellison Family Papers (NYHS). 
which rate might vary through our period from a low of four pence per foot of breadth ${ }^{14}$ to the high of three shillings per foot charged to a group of grantees who received title to grants by Coenties Slip between 1772 and $1775 .{ }^{115}$ The quitrents did not constitute the major cost to the grantees, however; no one ever seems to have complained that his quitrent was too high, although they regularly complained to the common council about the burdensome nature of their grants. The actual cost to the grantee in purchasing a waterlot was hidden in long, complicated, and highly formalized provisions of the grant.

Along with their lots and their potential profits, grantees accepted a set of restrictive covenants which ran with the land and which determined the precise ways in which the real estate would be developed. Satisfying the terms of these covenants was the major consideration paid by grantees. Almost uniformly the city required grantees to build two streets or wharves, one at either end of the length of their lots and each parallel to the river. These streets were to be constructed and paved by the grantees at their own expense, were to be dedicated and applied to the use of the public, and were to be maintained in perpetuity for the benefit of the public and the city by the grantee, his assigns or heirs.

Additional responsibilities specific to a particular grant usually were added. When in $\mathbf{1 7 5 8}$ the Corporation granted to Oliver Delancey a large lot on the Hudson in trust for the children of Sir Peter Warren, the deed included covenants for the construction of a forty-foot wide wharf or street on the inside boundary of the lot, a forty-foot wharf or street on the outside of the lot, a fifteen-foot wharf to run from Cortlandt Street to the river which would front a slip to be made and left by Delancey which would itself be dedicated to public use, plus two posts which were to be put on the latter wharf twenty feet from one another as an aid for boats that would dock there. Moreover, it was stipulated that "all profits, fees, perquisites, and Emoluments arising or accruing from the wharf or street" running by the slip, "shall be taken and received by the Mayor Aldermen and Commonalty" of the city. These covenants had to be satisfied within seven years or the Corporation would repossess; the waterlot might again become part of the estate of the Corporation. And until those terms were

\footnotetext{
114 Corporation Grant to Oliver Delancey, March 13, 1758, Delancey Deeds (NYHS) and Corporation Grant to Henry Bogart, May 15, 1739, Grant Book B (MARC), Corporation Grant to Elizabeth Sharpas, August 23, 1739, Grant Book B, MARC.

115 Corporation Grant to Hendrick Remsen, July 10, 1772, NYC Deeds, Box 8 (NYHS); Corporation Grant to Peter Jay, July 10, 1772, NYC Deeds, Box 8 (NYHS); Corporation Grant to James Van Cortlandt, Augustus Van Cortlandt and Frederick Van Cortlandt, February 3, 1773, NYC Deeds, Box 8 (NYHS); Corporation Grant to Elizabeth Delancey, April 29, 1773, BV Delancey Deeds, 1731-1784 (NYHS); Corporation Grant to Nicholas Gouvernor, March 21, 1775, Gouvernor Family Papers (NYHS).
} 
entirely satisfied the children of Sir Peter Warren could not profit from the development of their lot. ${ }^{116}$

Many grants included an obligation to construct a public space of some kind in addition to the streets at front and rear which were a uniform part of almost every grant. Frequently the grantee agreed to construct and maintain a public slip-the space between two piers-to dredge it and make sure that at all times it would be usable for deep water ships. All boats were "to have free liberty to load and unload goods, wares, merchandizes," at the slip. And the Corporation was to have "all profits, fees, perquisites, and emoluments" arising from the use of the side of the piers or streets that were directly contiguous to the slip. ${ }^{117}$ Other grants insisted on the construction of an extra dock, a bulkhead, or a third street.

At times the size and complexity of the "public works" required by the Corporation would be on such a scale as to necessitate joint enterprise by groups of merchants or neighbors. This was the case in 1772 and 1773 when a number of merchants applied for waterlots on the east side of Coenties Slip. ${ }^{118}$ The city insisted that any grant would be contingent on the construction of a large and costly public "basin" which forced the merchants to develop a formula for distributing the costs of the project. "[I]f Grants . . . should be obtained," wrote the applicants, "it would be necessary for them . . . to raise sundry large sums of Money in order to comply with the Terms upon which such Grants would probably be made and that as some of them ... would derive a greater Advantage from the said Grants than others and of consequence ought to bear a greater proportion of the Expence," it was decided that the task of ascertaining "the several and respective Proportions of the whole Charge" should be given over to arbitrators. These decided that both the costs of construction and maintenance and the eventual profits (the wharfage) should be divided in proportion to the breadth of the respective lots, and their report became a contract binding the parties. ${ }^{119}$

The available records do not indicate how frequently grantees redistributed the costs of construction among themselves through private

${ }_{116}$ Corporation Grant to Oliver Delancey, March 13, 1758, Delancey Deeds (NYHS).

117 See for example, Corporation Grant to Henry Van Borson, July 23, 1737, Grant Book B (MARC).

118 Corporation Grant to Hendrick Remsen, July 10, 1772, NYC Deeds, Box 8 (NYHS); Corporation Grant to James Van Cortlandt, Augustus Van Cortlandt and Frederick Van Cortlandt, February 3, 1773, NYC Deeds, Box 8 (NYHS); Corporation Grant to Peter Jay, July 10, 1772, NYC Deeds, Box 8 (NYHS); Corporation Grant to Elizabeth Delancey, April 29, 1773, BV Delancey Deeds, 1731-1784 (NYHS); Corporation Grant to Nicholas Gouvernor, March 21, 1775, Gouvernor Family Papers (NYHS).

119 Arbitrators Report, bound with Corporation Grant to James Van Cortlandt, et al, February 3, 1773, NYC Deeds, Box 8 (NYHS). 
agreements of this kind. But the very existence of such agreements demonstrates the inadequacy of a simple equation of waterlot grants with municipal corruption. Of course grantees applied for grants, anxiously worked out financing arrangements that would allow them to meet the terms imposed by the city, and usually abided by those terms for reasons which presumably had something to do with long-term economic advantage and gain. Grantees expected to benefit from their grants. And it may be that many of the recipients of grants got their waterlots because of their influence over and connections with the city council. But to look only to the private cui bono without at the same time considering the benefit to the city and its corporate entity is to lose sight of the calculated ways in which grants of property could function as instrumentalities of governmental action. The terms of the grants were shaped by the long-term interest of the city in a developed and expanded waterfront. It was up to the grantees to work out ways of meeting the terms set by the Corporation.

The control the Corporation exercised over granted waterlots was not limited to setting affirmative and executory duties. Grants often included restrictions on the timing of a development. ${ }^{120}$ In some cases they required construction of a project at some relatively distant point in the future, tying the actions of the waterlot holder to the future growth of the city or to some other contingent event. In the case of the "basin" grants of the 1770s the Corporation insisted that at the end of twenty years or as soon as the basin was filled in, the grantees would have to build a third street of $\mathbf{4 5}$ feet in width "so far as the right of the Mayor Aldermen and Commonalty extends." 121 Thirty-three years earlier Henry Bogart had similarly convenanted

that whenever hereafter it shall happen that three or more of the freeholders and Owners of the Lotts of Land and WaterLotts in the Neighborhood .. . shall Conclude and agree together to Erect and make wharfes and streets thereon and wharfe out and fill up the Same for better Improvement thereof into Hudsons River . . . that he the said Henry Bogart . . . at his . . . own proper Cost Charge and Expence shall wharfe out behind his said Ground and Lott . . . as far as the Neighborhood shall wharfe out and fill up behind their own Lotts. ${ }^{122}$

If the terms of the grant were fulfilled-that is, if the quitrent was paid every year, the covenanted streets, wharves, and other public facilities were constructed within the period of time set out in the deed, and all "public" parts of the property were properly maintained-then the Cor-

\footnotetext{
120 Corporation Grant to Cornelius Vanhorne, July 26, 1734, Grant Book B (MARC).

121 Corporation Grant to Hendrick Remsen, July 10, 1772, NYC Deeds, Box 8 (NYHS).

${ }^{122}$ Corporation Grant to Henry Bogart, May 15, 1739, Grant Book B (MARC).
} 
poration for its part covenanted that it would guarantee the good title of the grantee and warranted that he or she should be able to have the "quiet enjoyment" of the property in perpetuity. ${ }^{123}$ More pertinently to the presumed wants of the grantees, the Corporation also always covenanted that "in consideration of [the grantee and his or her heirs and assigns] . . . maintaining and keeping in repair the streets and wharfs before mentioned [they] shall and lawfully may at all times and from time to time for ever hereafter fully and freely have use enjoy take and hold to their own proper use and uses all manner of wharfage cranage benefits advantages and emoluments growing arising or accruing by or from the said wharf fronting the East River."

But if the terms of the deed were not satisfied by the grantee, then the document gave the Corporation a number of sanctions. Nonpayment of rent would give the Corporation the right to distrain the goods and possessions of the grantee. Ten days after the due date for payment of the quitrent, the agents of the city could enter onto the waterlot and "bear lead drive and carry away" all the movable property of the grantee until the rent had been paid. In some of the grants, moreover, the Corporation retained a right of entry as a further direct sanction against an unsatisfactory grantee. Under such a grant, a grantee who had not paid his rent or who had not properly built wharves, streets, or whatever, within the time period set out in the deed thereby gave to the Corporation the right to "Reenter' the property "and the same to have again, Retain, Repossess and Enjoy as their former Estate." Such a right of entry created a future interest in the waterlot that was retained by the Corporation even as it conveyed title to the grantee. And ultimately the fee simple received by the grantee was made conditional on the satisfaction of the covenants; failure by the grantee in meeting the Corporation's terms might result in a forfeiture to the Corporation. ${ }^{24}$

But in most cases the Corporation evidently saw no need to create a possibility of a forfeiture. ${ }^{125}$ The fact that a grantee who had not fulfilled the terms of his or her grant could not collect wharfage, slippage, pierage,

\footnotetext{
123 Such a warranty was uniform in grants made before the Revolution.

124 See Corporation Grant to Gerrardus Duyckinck, July 26, 1734, Grant Book B (MARC).

125 The Corporation in 1734 began by granting its waterlots with conditional rights of entry. But after 1735 most grants did not contain a right-of-entry provision. But see Corporation Grant to Abraham Mesier, July 4, 1760, Grant Book C (MARC); Corporation Grant to Robert Leake, August 1, 1763, Grant Book C, (MARC); Corporation Grant to Nicholas Roosevelt, March 7, 1765, Grant Book C, (MARC); Corporation Grant to Cornelius P. Low, October 28, 1765, Grant Book C, (MARC). It appears that the right of entry became a bargaining tool used by the city and grantees in exchange for larger grants (see the Low grant), or lower quitrents.
} 
cranage, and other fees for the use by others of the facilities constructed on the lot was sanction enough. Only a satisfactory grantee could profit by his investment in a waterlot.

The waterlot grants made by the city allowed it to shape, control, and profit from the development of the waterfront of the settled city, without any obligation to finance that development. This was not, however, a hidden form of "municipal socialism."' Planning through the disposal of waterlot grants by necessity would be an incremental process, dependent in every instance on private market forces. Only a merchant who expected to profit quickly and substantially from investment in a waterlot grant could be expected to seek or to accept such a deed. Under such a system of control, the construction of waterfront facilities would not move ahead of demand.

In the eighteenth century, as in every period of New York's history prior to the rise of the skyscraper, the seaport of the city dominated the shape of the city. Views of the city inevitably placed its harbor in the foreground, and travellers' accounts dwelt on New York's shipping facilities. Descriptions typically began with an account of the "multitude of Shipping with which it [the city] is thronged," 126 and continued with a comparison of the relative advantages and development of the ports of New York and Philadelphia. Doctor Alexander Hamilton "saw more shipping in the harbour" of New York, ${ }^{127}$ and Peter Kalm thought "New York probably carries on a more extensive commerce than any town in the English North American provinces," although "Boston and Philadelphia however come very close to it." ${ }^{128}$ Travellers agreed that the port was "a good one." Ships of any tonnage could lie in at the docks and wharves, and the facilities were sufficient to meet the demand. All boats could load and unload at dockside without the aid of lighters. ${ }^{129}$ Moreover, travellers and boosters alike thought that New York's salt water port gave the city a definite advantage over Philadelphia's location on a fresh water river which because it froze "During the Severity of Winter . . . is locked up from all marine Correspondence with the rest of the World, and thus, necessarily for several Months every Year, exposed to an almost total Stagnation of Trade." By contrast, "No Season prevents our

126 Thomas Pownall, A Topographical Description of the Dominions of the United States of America (Being a Revised and Enlarged Edition of [A] Topographical Description of such Parts of North America as are Contained in the (Annexed) Map of the Middle British Colonies, \& c. in North America) 43 [1784] (Lois Mulkearn ed. 1949).

${ }^{127}$ Gentlemen's Progress. The Itinerarium of Dr. Alexander Hamilton. 1744, at 44 (Carl Bridenbaugh ed. 1948).

${ }^{128} 1$ Peter Kalm's Travels in North America 124 (Adolph Benson ed. 1937) [hereinafter cited as Kalm].

$1291 \mathrm{Kalm} 133$; Gentlemen's Progress, supra note 127, at 39. 
[New York's] Ships from launching into the Ocean and pursuing their Traffick-The Depth of Winter scarce obstructs our Commerce, and during its greatest Severity, an equal unrestrained Activity runs thro' all Ranks, Orders and Employments." 130

But as of 1770, and indeed throughout the eighteenth century, shipping tonnage arriving and clearing in New York City lagged well behind other major colonial ports. ${ }^{131}$ Carl Bridenbaugh and other historians have argued that New York's comparative and competitive failure resulted from the policies of its government. The mayor and common council "failed to provide their city with all the facilities it needed," ${ }^{132}$ and "No town was so poorly equipped to care for its shipping as New York." "133 They may be correct in their condemnation of the actions of the city, although their evidence is impressionistic and their judgment ultimately founded on the misperception that waterlot grants were unrestricted gifts of property. But the causal relationship between governmental land use planning and economic growth and change remains a most controversial and largely unexplored area of economic and historical research. ${ }^{134}$ And it is beyond the scope of this study to say whether New York's technology of planning constituted the most efficient choice available.

What can be said is that the waterlot grants made by the Corporation changed the face of the city. Over the last two-thirds of the eighteenth century, the harborside facilities of New York were transformed. Two full blocks were reclaimed out of the East River. The city had once ended at Pearl Street; by the end of the century Front Street had become the southeastern border of lower Manhattan. ${ }^{135}$ Perhaps the city would have grown at the same or even a greater rate had some other form of planning or port development been in effect. It is a certainty, however, that waterlot grants were used, as they were designed, to provide New York City with the streets, wharves, and port facilities of a growing seaport. ${ }^{136}$

130 The Independent Reflector 436; 1 William Smith, The History of the Province of New-York, 201-02 [1757] (M. Kammen ed. 1972) 1 Kalm at 133; Pownall, supra note 126, at 45 .

13! Robert G. Albion, The Rise of New York Port 5 (1939).

132 Gentlemen's Progress, supra note 127, at 39; Konvitz, supra note 93, at 65.

${ }^{133}$ Carl Bridenbaugh, Cities in the Wilderness 328 (1955).

134 The central text on the problem is J. Willard Hurst, Law and Economic Growth (1964).

135 See the maps collected in I. Phelps Stokes, The Iconography of Manhattan Island (1915-1928).

136 To say that the waterlot grants served to provide needed port facilities for the growing city is not to say that they may not also have created new health hazards for a town which had once prided itself on its healthful environment. See Cadwallader Colden to Dr. John Mitchell, November 7, 1745 (writing in the wake of an attack of yellow fever on the city), Colden Papers, vol. 8, NYHS Collections 329-30 (1934); see also The Independent Reflector 434-55 (on the "putrid stench" of Rotten Row). 


\section{The Governmental Theory of a Waterlot Grant}

It is important to underscore the peculiar nature of the waterlot grants made by the Corporation in the years after the reception of the Montgomerie Charter. If we look at them as the conveyances of a private landowner, they seem to violate several fundamental tenets of the law regarding real covenants. They specified affirmative obligations on the estate of the grantee that not only radically limited the uses to which he or she might put the lot, but also directed the actual shape of its development. Insofar as the satisfaction of those covenants was ensured through a clause granting the Corporation a right of entry whenever the grantee should fail to meet the terms set out in the deed, they were effectively transformed into conditions subsequent; and the grant became a grant of a fee simple subject to a condition subsequent rather than a fee simple absolute. But treatise writers from Coke on had emphasized that conditions subsequent were not to be favored in the law. ${ }^{137}$ And even when-as was more frequently the case in the grants made by the Corporationonly the right to take the profits from the waterlots was made conditional on the performance of the covenants in the grant, those conveyances still merged or "confused" covenants with conditions in ways that property lawyers would have found profoundly unsettling. ${ }^{138}$

Looked at as the planning tools of a municipal government the waterlot grants are equally perplexing. Here we have the Corporation of the city of New York with absolute ownership of the most important real estate in the city of New York; it controlled a central resource for the commercial development of the community. Yet it chose to act, if at all, through indirection. The Corporation might have planned the design of the waterfront of the city and then implemented that scheme, directly. Instead, it granted away the property and then compelled its grantees to develop their grants according to Corporation directives. The structure of action thereby created would appear to be an open invitation to inefficiency and corruption. And it is no wonder that historians of city planning might have viewed the actions of the Corporation as a wholesale surrender of its proper responsibility.

Nor can it be argued that the Corporation negotiated the kinds of grants it made because that was the only kind of grant any member of the common council could have imagined making. The Corporation of course could have simply disposed of the waterlots and thereby given up control over the development of the waterfront. Indeed at an earlier time, the city

${ }^{137}$ See 4 Kent, Commentaries on American Law 127-28 (2d ed. 1832).

${ }^{138}$ See the arguments of Alexander Hamilton and Robert Troup in Mayor v. Scott, 1 Caines Rep. 543, 548 (N.Y. Sup. Ct. 1804). 
had made relatively unrestricted grants of the waterlots between high and low water marks that it received under the Dongan Charter of $1686 .{ }^{139}$ And throughout the prerevolutionary period, whenever Corporation authorities chose for one reason or another to sell an occasional lot out of the commons, the grant memorializing the conveyance lacked any of the covenants or conditions that characterized the city's waterlot grants. ${ }^{140}$ One can only surmise that waterlot grants were drafted in their particular form because the governing members of the Corporation intended to control the development of the waterfront of the city. But again, if control and authority were what the Corporation of the city of New York was after, why did it choose this way of achieving it? Liverpool, after all, provided an alternative model of an English city that had developed its corporate estate directly by building a great and usable waterfront facility. ${ }^{141}$

We do not and probably cannot know why city authorities chose in the early 1730s to adopt the policy of making waterlot grants to individuals willing to develop their lots in accordance with the strict directives of the Corporation. But it is possible to understand what made such a policy attractive and plausible. The structure of action revealed in the waterlot grants may constitute a unique and attractive form of public action in an eighteenth-century political culture in which all direct forms of public action were constitutionally suspect. Liverpool, the model for the Webbs of an activist municipal corporation, stood alone throughout the eighteenth century. Other English commercial cities, notably Bristol and London, found it impossible to follow Liverpool's example and develop their waterfronts directly. ${ }^{142}$ By contrast, the use of land grants as planning tools had roots in an English planning tradition that stretched back to the new towns created by Edward I in the thirteenth century. ${ }^{143}$ Waterlot

\footnotetext{
139 On September 7, 1692, the Corporation made grants of lots between high and low water mark to William Morris, Hephanus Van Cortlandt and Dirrick Van Den Bergh. Each agreed to pay one peppercorn per year quitrent and to construct and maintain one street thirty feet in breadth on the inside of the lot. Failure to perform the latter covenant on time would result in a fine of twenty shillings for every month's delay, but the profits were not made contingent on the completion of the project. In fact, the city covenanted that the grantees had an absolute right to the profits and that the Corporation would make good any losses suffered by the grantees. Grant Book A (MARC). See also George Ashton Black, Municipal Ownership of Land on Manhattan Island 21, 27 (1891), who argues that after 1686 the lots between high and low water mark from Wall Street to Beekman's Slip were sold at public auction in fee simple absolute without the reservation of a quitrent.

${ }_{140}$ See, e.g., Release of the Corporation to William Walderon, September 24, 1731, NY City Deeds, Box 4 (NYHS); Counterpart of 33 year lease to Ann Aerison, April 24, 1771, Grant Book C (MARC).

1412 Sidney Webb \& Beatrice Webb, The Manor and the Borough 481-91 [1908] ("England Local Government vols. 2-3," 1963 ed.); Vigier, supra note 86, at 40-43.

142 Webb, supra note 141 , at $460-1$ (Bristol), 690 (London).

143 John W. Reps, Tidewater Towns 1-22 (1972).
} 
grants that covenanted action by their recipients offered the city a way to initiate change without doing violence to some of the central tenets of eighteenth-century political culture. Waterlot grants were a legitimate form of governmental action. Their use demonstrated a form of governmental power given to the Corporation through the property rights contained in the Montgomerie Charter that was unavailable to the unchartered local governments of eighteenth-century America.

In eighteenth-century terms the best answer to the question of what the purpose of government should be would have been that government ought to do little; its role was to make certain that others did as they ought to. One could not separate public from private action. Just as a "public" institution had "private" rights, so private individuals had public obligations. The primary function of government was to enforce the peace of the community; to maintain the order of society by insisting that private individuals fulfilled their public responsibilities. ${ }^{144}$

There was, as a result, little that one could consider direct governmental action or service. Governments did not act so much as they ensured and sanctioned the actions of others. The characteristic forms of "public" action were not street cleaners or road-building crews, but rather ordinances obliging residents to clean the portions of streets abutting their houses or presentments against the selectmen of a town (or a group of neighbors) for failing to maintain or repair a road or highway. ${ }^{145}$ Or, in New York City's case, public action took the form of a lease or grant of corporation property.

The problem of governance in New York City, as everywhere in provincial America, was to shift the burden of action to private individuals. One useful way of reading the ordinances of an eighteenth-century corporation is as a way of organizing private action. New York City's ordinance to pave and clean the streets, for example, had nothing to do with the "bureaucratic'" problem of providing a public service. Mobilizing an army of public servants would never have occurred to the members of the common council; indeed, it would have been definitive of their notion of corrupt government. Rather, the ordinance was a list of things that homeowners could or could not do in the care of their streets, in the care of that portion of the streets that fronted their properties. ${ }^{146}$

${ }^{144}$ This argument is spelled out in greater detail in Hendrik Hartog, The Public Law of a County Court; Judicial Government in Eighteenth Century Massachusetts, 20 Am. J. Legal Hist. 282-329 (1976). For an examination of the dependence of whig-republican theory on the existence of an active and virtuous public, see J. G. A. Pocock, The Machiavellian Moment (1975).

14. Maitland, Township and Borough (1898); see also Vigier, supra note 86, at 54-55.

146 New York City, Laws, Orders, and Ordinances (November 18, 1731), c. 22; New York City, Laws, Statutes, Ordinances, and Constitutions (1749), c. 14; New York City, Laws, Statutes, Ordinances and Constitutions (1763), c. 14. See note 67 supra. 
Even when governmental action involved the city's own corporate estate, the role of the city was usually limited to a supervisory and directive one. If a slip had to be cleaned, the landowners whose property abutted the slip would be ordered to clean it at their own cost. In 1737 a grand jury presented the public pier near Fly Market as a nuisance because it was "so narrow that [it] often proves Very dangerous as to Carts passing and Repassing both in Respect to grown People as well as Children," and the members of the jury ordered the residents living near the market to petition the common council for permission to enter onto the Corporation's property in order to widen the pier. ${ }^{147}$ When in the same year William Cornell, the lessee of the ferry, complained that the disrepair of the markethouse at Clarke's Slip was cutting into his business by discouraging "Country People' from coming to the city, he did not conclude his petition as we might have expected by asking the Corporation to maintain its property properly. Instead, he asked the common council to order the neighbors of the markethouse to repair it (an order which was preempted by a petition by those very neighbors who volunteered to enlarge and improve the markethouse).${ }^{148}$ No one, it seems, even contemplated asking the Corporation to take care of its own property directly.

At one level, the insistence that action be conducted by private individuals might be regarded as a substitute for a nonexistent public bureaucracy. Public action depended on the participation of a local public. ${ }^{149} \mathrm{But}$ that insistence was as deeply tied to the belief that government ought not to bear the costs of action. Perhaps the most striking manifestation of that belief from our perspective lay not in what we might consider local government at all but in the presumption in criminal courts throughout colonial America that defendants ought to pay the fees and costs for their trials irrespective of whether or not they were acquitted. ${ }^{150} \mathrm{We}$ can also see that belief reflected in many elements of the practice of the common council of the city of New York prior to the second half of the eighteenth century. Virtually every order the council made was premised on the conviction that whatever was going to be done the Corporation would not pay for it. Lessees of the Corporation-whether of the ferry, the public docks, or land in the commons-held their leases subject to their willingness to assume all liability for repairs or improvements. ${ }^{151}$ The very oath taken by

${ }^{147} 4 \mathrm{MCC} 403$ (The petition of the residents was, not surprisingly, granted.)

${ }^{148}$ Petition File, 1737 (MARC).

${ }^{149}$ A similar argument is developed for Massachusetts in William E. Nelson, The Americanization of the Common Law 13-35 (1975); and in John P. Reid, In a Defiant Stance: The Conditions of Law in Massachusetts Bay, The Irish Comparison, and the Coming of the American Revolution (1977).

${ }^{150}$ Julius Goebel, Jr. \& T. Raymond Naughton, Law Enforcement in Colonial New York 731-48 (1944); Hartog, supra note 144, at 320, 326-27.

151 The responsibility of the lessee of the ferry for all repairs led to constant petitions 
a freeman made his obligation to avoid imposing costs on the Corporation second only to his responsibility to maintain the property of the Corporation. ${ }^{152}$

Indeed, one might argue that the estate granted in the charters was less important to the Corporation as a way of generating revenue than as a tool of governance that vitiated the need for revenue. Of course the corporate property gave the city an income freed from the restrictions of dependence on the provincial assembly, thus providing a partial and temporary substitute for tax revenues. But the waterlots and other parcels of corporate property also offered city authorities the opportunity to act without any costs of municipal administration. As we have seen, the Corporation uniformly required waterlot grantees to build streets or wharves at the front and at the rear of their holdings. These covenants should be read as meaning exactly what they say. The city was not simply reserving a portion of the granted lands for public uses, nor was it merely assessing the costs of street construction. These covenants meant that the city would do nothing, the waterlot holders everything. It was the waterlot grantees who would build and finance the public streets by the side of the harbor of New York City.

The government of New York was a government which acted by delegation, a government committed to a policy of externalizing the costs of action, yet, at the same time, a government lacking most of the powers of coercion and enforced obedience of the modern state. Neither the "watch," nor the constabulary, nor the sheriff and his deputies constituted what we would consider a police force. Compared to the monopoly on legitimate violence of the modern positivist state, government at every level in eighteenth-century America was relatively ineffectual. In this regard the government of New York City was indistinguishable from other local governments. Public action was possible only to the extent that a government could enlist the support and involvement of a local constituency. ${ }^{153}$

\footnotetext{
asking for reduction or abatement on the rent in order to meet the costs of maintenance or repair of the docks from which the ferry left. Frequently the Corporation granted those petitions, and in a sense the Corporation did therefore "pay" for repairs. But the Corporation was far less concerned with the size of its revenue than with the avoidance of all direct responsibility for action.

1524 Common Council 121 (1731).

${ }^{153}$ See for example, the Petition of the Vestrymen, Petition File, 1755 (MARC), who asserted that the keeper of the almshouse did not perform the duties of his station and behaved in a surly and abusive manner to justices of the peace and vestrymen. If he were not fired immediately the vestrymen threatened that they would not attend to their monthly meetings "with that Alacrity and Chearfullness as they would Willingly do for the Publick Good."
} 
Dependence on the participation of a local public meant that most local governments operated with a very limited range of objectives. Governments pursued consensus as the only legitimate basis for action; when consensus was unachievable, governments did nothing. Others have written of the committed and conscientious parochialism of local government in the province of New York, and some historians have concluded that all forms of government in eighteenth-century America sought to preserve a consensually determined status quo. ${ }^{154}$ But different publics might come to differing conclusions as to the proper sphere of public action. And in New York the members of the common council could legitimately-within the terms of the political culture-direct the actions of the city towards change, planning, and development. New York City was preeminently a commercial city, whatever ambiguities there may have been in the definition of the role of government within that conception of the community. Shipowning was widely dispersed throughout the population of the city ${ }^{155}$ virtually every family in the city was involved in seaborne commerce. The development of the waterlots of the city were not merely for the benefit of a small elite. In effect the terms of the grants provided a form of redistribution from the wealthy to the larger community of the city, which would bear none of the costs of development. The fortunes of nearly everyone in the small city of New York would ride on the quality and the quantity of the city's harbor facilities. ${ }^{156}$ And while William Livingstone thought that the Corporation's dealings in making waterlot grants meant that council members would eventually "experience the Resentment of an injur'd People, at a Time when they are most solicitous about the popular Esteem," ${ }^{157}$ it may be that he was wrong. The Corporation may have used its corporate estate in ways that accurately reflected the desires of its constituents.

In any event, the property rights granted New York City through its charters allowed it to achieve governmental objectives that were beyond the reach of unpropertied local governments. Instead of mere sanctions against failures of performance, the city could offer leases, licenses, and

154 See Patricia U. Bonomi, Local Government in Colonial New York: A Base for Republicanism in Colonial New York Society and Politics 29 (J. Judd \& I. Polishook eds. 1974); William Nelson, The Eighteenth-Century Background of John Marshall's Constitutional Jurisprudence, 76 Michigan L. Rev. 893-960 (1978); Michael Zuckerman, Peaceable Kingdoms (1970); Sung Bok Kim, Landlord and Tenant in Colonial New York (1978).

155 Bruce Wilkenfeld, The New York City Shipowning Community, 1715-64, 37 American Neptune 50-65 (1977).

156 The significance of shipping facilities to a city whose population never exceeded 22,000 in the colonial period would be of a piece with the significance to a modern university town of the school's legislative appropriation or the level of student enrollment.

157 The Independent Reflector 156. 
grants to private individuals willing to implement various city-defined goals. New York City did not itself build streets, fill in swampland, or dig wells; the public works projects that characterized nineteenth-century urban government would have been incomprehensible to the city fathers of eighteenth-century New York. Yet it could act. Where a county court could only indict a town or individual for failing to maintain a street or bridge, New York's property gave it a way of building streets and bridges; the property of the city allowed it to plan and initiate action without doing violence to the basic premises of eighteenth-century governance.

The waterlot grants of New York City thus typify the singular governmental authority of a propertied corporation. Their terms made possible a form of capital investment and development without a reliance on the exactions of the tax gatherer or the exertions of a public bureaucracy. They suggest the possibility that even within the terms of a political culture opposed to publicly instituted change and innovation, a propertied corporation could control the continuing evolution of the shape of a community. In a world of governance in which the enforcement of public policy (indeed its very formulation) was prima facie corrupt absent public consensus, in which instrumental public action was inherently suspect, ${ }^{158}$ the waterlot grants of the city constituted a technology of public action that was prima facie legitimate and proper. It was not a standing army or a police force that gave effect to the decisions of the city government; it was the hallowed operation of English property law. The fact that the Corporation held its property as a private landowner made it possible for the city to delegate to private individuals major responsibility for the construction of its commercial heart without at the same time abandoning control over that process.

\section{CONCLUSION}

After the middle of the eighteenth century there are signs that the political assumptions of local governance in America were beginning to change. More and more governmental activity was made directly chargeable to the New York City Corporation. In 1755 the common council made a standing rule that whenever repairs to public wharves were necessary, the aldermen and assistants of the ward where the wharves were located should proceed immediately to contract out the work and charge the costs to the Corporation. ${ }^{159}$ And by 1767 a group of merchants might

158 See John Phillip Reid, In Legitimate Stirps: The Concept of "Arbitrary," the Supremacy of Parliament and the Coming of the American Revolution, 5 Hofstra L. Rev. 459-99 (1977); Bernard Bailyn, The Origins of American Politics (1968).

1591 Stokes, supra note 135, at 197. 
petition the Corporation about the sorry state of Beekman's Slip with the expectation that the common council would respond by appointing a committee with power to correct the situation directly, placing the whole cost on the Corporation. ${ }^{160}$ Indeed, the growing dependence of the city on the taxing powers of the provincial assembly because of the city's increasing inability to finance its work out of corporate income may be one indication of increased willingness to internalize within the government the costs of action. ${ }^{161}$

Perhaps the theoretical underpinnings of local governance in colonial America were beginning to fall away. There is some evidence of what might be called a bureaucratization of public affairs elsewhere. And there are clear indications of a new dependence on public authority. ${ }^{162}$

Yet the scope of public activity did not grow; there is no evidence of a general reevaluation of the legitimacy of direct public action. The increased willingness of the Corporation to assume the costs of maintaining corporate property may rather indicate that the common council was increasingly conscious of a problematic separation of the estate of the Corporation from the general government of the city. After the Revolution, consciousness of that separation would grow, eventually becoming a central obsession of the American law of municipal corporations. But in the $1750 \mathrm{~s}, 60 \mathrm{~s}$, and $70 \mathrm{~s}$ the dichotomous relationship of public power and private wealth was at most only a subterranean theme in the institutional history of New York City. New York City continued to govern through its corporate estate. Waterlot grants remained at the center of the city's governmental business right up until the city was abandoned to the British in 1776.

The waterlot grants of New York City were one solution to the problem of how an eighteenth-century commercial city could develop its commercial facilities. Such activity may be a prototypical example of the " privatism" that we so deplore in modern life: the subsidization of private gains by public agencies and the definition of social goals in terms of private advantage. But from a less presentist perspective, waterlot grants offered the possibility of achieving positive governmental goals at a time when there was no theory of direct governmental action. How do you get

1607 Common Council 77-79.

161 Edwards, Municipality, supra note 46, at 35, 190-205; it is important to note that after 1750 criminal courts also increasingly made the costs of trial a governmental responsibility. Goebel and Naughton, Law Enforcement in Colonial New York, 731-748, Hartog, Public Law of a County Court . . . 326-7.

${ }^{162}$ See generally, Kenneth Lockridge, Social Change and the Meaning of the American Revolution, 6 J. Soc. Hist. 403 (1973), Douglas Jones, The Strolling Poor, Transiency in 18th Century Massachusetts, 8 J. Soc. Hist. 28 (1975), Hartog, supra note 144, at 282; James A. Henretta, The Evolution of American Society, 1700-1815, at 119-57 (1973). 
something done if you do not know how or, rather, if you cannot conceive of doing it yourself? You get someone else to do it for you. In colonial America and in Georgian England most local governments could only get those things done that had always been done, or that had at least always been supposed to be done, since the only sanction available was punishment for not acting. One cannot after all punish someone for not doing what he or she was not obliged to do. On the other hand, a chartered city with a substantial estate could use its wealth to achieve goals, to induce change, even in the absence of a commitment to direct governmental action. The promised reward of the waterlot (and its profits) gave the city the power to coerce grantees to do things that they were not obliged as citizens to do. And ultimately our interest in the practice of government in eighteenth-century New York City is defined by that possibility of action, by the ways in which the seemingly distinct public and private spheres were united in the achievement of positive governmental goals. 